\title{
Mitigating eutrophication nuisance: in-lake measures are becoming inevitable in eutrophic waters in the Netherlands
}

\author{
Miquel Lürling (D) Maíra Mucci
}

Received: 1 August 2019/Revised: 21 April 2020/Accepted: 14 May 2020/Published online: 22 May 2020

(C) The Author(s) 2020

\begin{abstract}
In the Netherlands, legacies and diffuse nutrient pollution continue to fuel recurrent cyanobacterial blooms in mostly shallow and relatively small surface waters. A survey in peer-reviewed literature and Dutch grey-literature was performed to gain insight into the physical-, chemical- and biological in-lake interventions used to bring these waters towards their desired state. A critical overview is presented on efficacy of different measures to counteract cyanobacterial blooms directly via targeting the cyanobacteria or indirectly via reduction of nutrient availability. Many actions have no or limited effects on minimising cyanobacterial blooms (air-bubble- or oil screens, surface mixers, low-energy ultrasound, effective micro-organisms, fish introduction), while others are more effective, but may vary in longevity and costs (dams, excavation or dredging, hydrogen
\end{abstract}

Guest editors: Tom Jilbert, Raoul-Marie Couture,

Brian J. Huser \& Kalevi Salonen / Restoration of eutrophic lakes: current practices and future challenges.

\section{Lürling $(\varangle) \cdot$ M. Mucci}

Aquatic Ecology \& Water Quality Management Group,

Department of Environmental Sciences, Wageningen

University, P.O. Box 47, 6700 AA Wageningen, The

Netherlands

e-mail: miquel.lurling@wur.nl

\section{Lürling}

Department of Aquatic Ecology, Netherlands Institute of Ecology (NIOO-KNAW), P.O. Box 50,

6700 AB Wageningen, The Netherlands peroxide, phosphorus inactivation agents), meet legislation restrictions (copper-based algaecides, herbicides, dreissenids), or are not currently implemented (hypolimnetic withdrawal). The selection of promising interventions requires a proper diagnosis of each problem lake, based on water- and nutrient fluxes, the biology of the lake (plants, fish), the function of the lake and the characteristics of the method, such as efficacy, costs, safety and ease of implementation. In the Netherlands, ongoing diffuse loads and legacies necessitate repetitive in-lake interventions.

Keywords Cyanobacteria blooms - Geoengineering · Harmful algal blooms · Internal load . Lake restoration

\section{Introduction}

Nutrient losses from inadequate wastewater treatment, soil erosion and intensified agricultural activities lead to ongoing eutrophication of inland waters with forecasted climate change to further exacerbate this over-fertilisation and its symptoms (Forsberg, 1998; Cordell et al., 2009; Jeppesen et al., 2009; Moss et al., 2011; Sinha et al., 2017; Beaulieu et al., 2019). Accordingly, cyanobacterial blooms, as a key symptom of eutrophication in lakes, ponds and reservoirs (Smith et al., 1999), show a worldwide proliferation 
(Paerl \& Huisman, 2008; O'Neil et al., 2012; Paerl \& Paul, 2012; Huisman et al., 2018). Such increased incidence, intensity, and duration of cyanobacterial blooms comes with nuisance, such as consequences for human- and environmental health effects; nasty odours, high water turbidity, fish kills, food web alterations and impairment of important ecosystem services, such as drinking water preparation, irrigation, recreation, aquaculture and fisheries (e.g. Pearl \& Paul, 2012).

Although it has already been known for decades that over-fertilisation of surface water can lead to impaired water quality and cyanobacterial blooms (Edmondson et al., 1956; Parma, 1980), eutrophication is still the most important water quality issue worldwide (Smith \& Schindler, 2009; Downing, 2014). Minimising external nutrient inputs is a straightforward management strategy (e.g. Hamilton et al., 2016; Paerl et al., 2016; Huisman et al., 2018), but globally, even point source nutrient pollution from wastewater is not being addressed adequately (WWAP, 2017). In low-income countries, less than $10 \%$ of the municipal and industrial wastewater undergoes treatment of any kind, while high-income countries treat about $70 \%$ of their wastewater (WWAP, 2017).

Nonetheless, even if point source nutrient pollution is being reduced satisfactorily, this is no guarantee for diminished eutrophication issues. The water quality in the Netherlands provides a clear example. The Netherlands is one of the few countries in the European Union, in which urban wastewater treatment is in full compliance with the Urban Waste Water Treatment Directive, including 100\% compliance for tertiary treatment targeted at the elimination of nutrients (EU, 2013). The average nutrient removal efficiency from municipal wastewater was $84.5 \%$ for nitrogen and $86.8 \%$ for phosphorus in 2016 (CLO, 2018). Despite over $99 \%$ of the wastewater being treated, the Netherlands has one of the poorest surface water qualities of the entire European Union with $40 \%$ of its lakes in a moderate ecological status $(n=179)$ and $60 \%$ having a poor or bad status $(n=269)$ (EEA, 2018). Furthermore, it is expected that even when all Water Framework Directive (WFD) measures have been fully implemented, only about $40 \%$ of the Dutch water bodies will meet the WFD goals in 2027 (CBS, PBL, 2012). This is because legacies from the past, sewage overflows and diffuse pollution, will continue to exert a strong impact on water quality (OECD, 2014).

The main pressure on the Dutch surface waters is diffuse pollution, which originates mostly from massive agricultural industry (EU, 2017). The Netherlands is the world's second largest exporter of agricultural goods, which represented an export value of 90.3 billion euros in 2018 (CBS, 2019a) and 94.5 billion euros in 2019 (Jukema et al., 2020). Here, the meat sector represents one of the largest exporters, contributing 8.6 and 8.8 billion euros in 2018 and 2019, respectively, which implies that about three-quarters of Dutch meat is being exported (COV, 2019). Consequently, in 2017 the surplus of nitrogen (N) was 319 million $\mathrm{kg}$, of which 225 million $\mathrm{kg}$ was lost to the soil and 94 million $\mathrm{kg}$ to the atmosphere, while for phosphorus (P) the surplus that ended-up in the soil was 4 million $\mathrm{kg}$ (CBS, 2019b, c). In 2016, the load of nutrients that leached from soil to surface waters was 44.6 million $\mathrm{kg} \mathrm{N}$ (58\% of total load) and 3.95 million $\mathrm{kg} \mathrm{P}$ (62\% of total load) (CBS, 2018). Such high diffuse sources imply that in the Netherlands, within-system interventions are inevitable to reach a water quality that meets societal demands for recreation or as set by legislation (e.g. WFD). In this study, we discussed the need for in-lake actions, while showing a survey of peer-reviewed literature and Dutch grey-literature to gain insight into different types of measures (physical, chemical and biological), highlighting the importance of proper system diagnosis before any intervention. In addition, several examples of (un)successful effect-oriented measures in relatively small shallow urban Dutch waters are given.

\section{Most Dutch water bodies are shallow}

In the Netherlands, the vast majority of the water bodies are shallow systems that originate from largescale removal of peat and reclamation of former sea (Gulati \& Van Donk, 2002). They range from a few hectares to the $1,100 \mathrm{~km}^{2}$ of Lake IJsselmeer. In addition, the country harbours thousands of shallow urban waters. The exact number is not known, but in the province of North Brabant the total number of urban ponds is already 3,473 (Waajen et al., 2014). These often relatively small urban waters, despite being used intensively by citizens, are mostly a blind 
spot to water authorities, as they are not included in regular monitoring programmes (Waajen et al., 2014). For instance, in the WFD water quality monitoring, the Netherlands does not include lakes smaller than 50 ha (EC, 2012). Nonetheless, every year hundreds of sites experience massive cyanobacterial blooms (Fig. 1).

All these shallow waters can be in a clear water state with submerged macrophytes or in a turbid state without submerged macrophytes, but with high phytoplankton biomass (Scheffer et al., 1993). Whether the shallow water body is in a clear water state or a turbid state is highly dependent upon the nutrient load. Turbidity increases with the nutrient load (both $\mathrm{N}$ and P) due to increased phytoplankton growth (e.g. Rabalais, 2002; Scheffer \& Van Nes, 2007), while turbidity reducing vegetation disappears when a critical turbidity is exceeded (Scheffer \& Van Nes, 2007). In this context, a critical nutrient load can be defined as a maximum nutrient load that a system can adsorb, while not changing trophic states. Thus, if the system is below the critical nutrient load, from turbid to clear, the water will remain clear; and, above the critical load, from clear to turbid, the water will be turbid (Scheffer et al., 1993). The turbid state is often a cyanobacteria-dominated state (Scheffer et al., 1997; Fig. 1). In between the two transitions (caused by hysteresis due to state stabilising factors), both states are possible (Scheffer et al., 1993). Hence, it is crucial to determine what the actual nutrient loads are, as well as the estimated critical loads, which can be evaluated through models, for instance, for shallow lakes using the model PCLake (Janse et al., 2010).

Determination of water- and nutrient flows is a part of the diagnosis required to decipher the most nutrient important sources. The diagnosis also determines if the cyanobacterial nuisance that can be defined as recurrent- or persistent blooms cause disruption to services provided by the lake, originate in the water

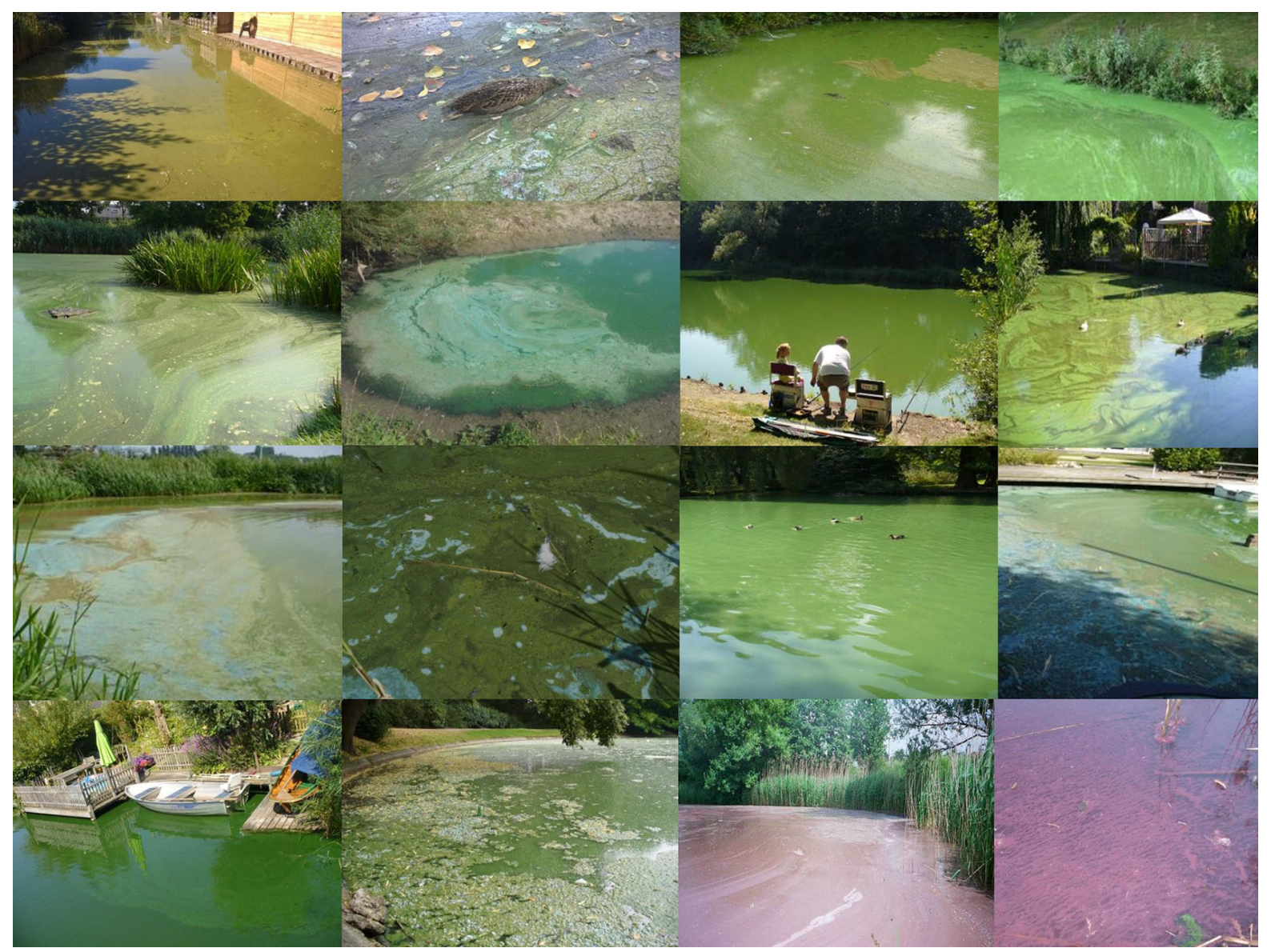

Fig. 1 Pictures of some Dutch urban waters that annually suffer from cyanobacterial blooms 
column or are from an accumulation of cells grown elsewhere that have been blown to leeside shores (Chorus et al., 2000). It includes analysis of the biological characteristics of the system, because in the process of becoming nutrient-enriched, an increase in phytoplankton biomass, loss of submerged plants, accumulation of organic matter and nutrients in the sediment, changes in zooplankton community structure to small-bodied grazers, and an increase in planktivorous and benthivorous fish biomass, may have occurred (Moss, 2010). This biological characteristics stabilises the turbid phytoplankton dominated state (Scheffer et al., 1993) and consequently measures aimed at reducing turbidity might be needed (Fig. 2). Depending upon the nutrient source (diffuse/point, external/internal) and its magnitude, a variety of in-lake measures may need to be implemented (Fig. 2).

\section{Within-water body interventions}

The within-system actions are mostly directed towards controlling cyanobacterial blooms, although massive submerged or floating plant growth may also cause annoyance and issues with use of the water. Withinsystem interventions are mostly so-called 'effectoriented' measures that may either target the cyanobacteria directly (symptoms-oriented), or indirectly, via strong reduction of available resources (source-oriented). Measures are mostly aimed at preventing inflow of surface accumulated cyanobacteria in harbours, beach areas etc. removal of surface scums, removal of biomass, killing cyanobacteria and preventing their proliferation. Among effect-oriented measures, a huge variety of untested and unverified solutions are being advertised (Van de Graaf, 2016), in which, in many cases, solid scientific understanding of the supposed working mechanism is lacking. Scientific testing of some end-of-pipe solutions revealed that they are not as effective as claimed (Lürling et al., 2016a), and an overview over several interventions

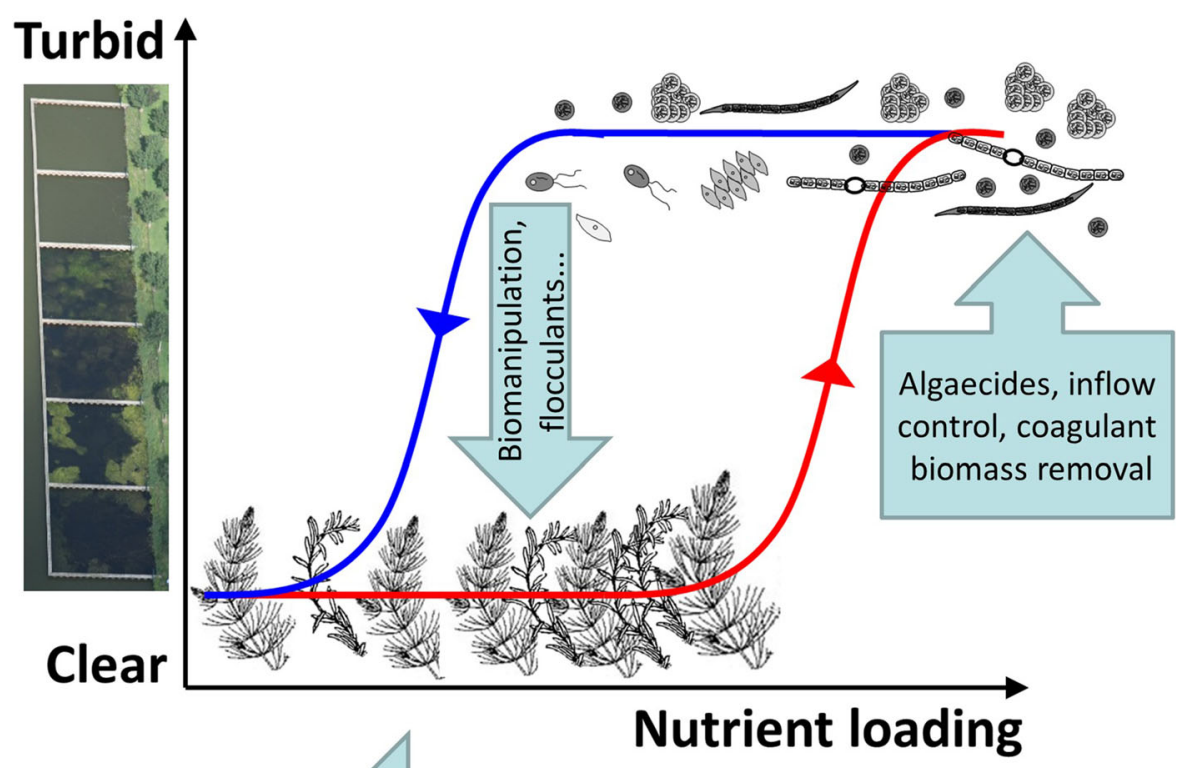

Inflow and sediment nutrient reductions, dredging, P-fixation...

Fig. 2 Typical hysteresis of nutrient loading and water transparency in shallow lakes. Successful restoration requires interventions along both axes 
has been given recently by Stroom and Kardinaal (2016). In this section, experiences from several inlake measures in the Netherlands are listed. Important criteria for being considered as a useful measure are that the method should first of all be effective, i.e. in reducing the nuisance strongly and preferably for at least the entire recreational season, it should be safe for the environment, relatively easy to apply, and should not be too expensive (Lürling et al., 2016b). In general, effect-oriented measures can be divided into physical-, chemical-, and biological methods (Stroom \& Kardinaal, 2016).

\section{Physical methods}

Several physical methods to prevent inflow of surface accumulated cyanobacteria and to remove surface scums were already been reported in 1992 (STOWA, 1992). Some of those, such as an air-bubble screen, have been implemented in the Netherlands. An airbubble screen was installed in the harbour of Lake Meerzicht in 1986 that reduced accumulation of cyanobacteria in the harbour by $80 \%$, but no further details were reported (Van der Veer et al., 1993). Another report mentioned that approximately $75 \%$ of the scums were stopped (STOWA, 1992), which was based on 'visual inspection'. A similar screen was implemented to protect the harbour of Almere-Haven in 2006 and 2007 (Fig. 3A), with mixed results (Burger et al., 2007).

Surface aerators or mixers can be found in many ponds and harbours that exist to prevent the surface accumulation of cyanobacteria and to reduce bad odours (Fig. 3B, C). Fountains are also used to mix the water (Fig. 3E), but in general, their efficacy in preventing a bloom is limited, as fountains do not reduce nutrients or kill cyanobacteria. For instance, summer cyanobacterial chlorophyll- $a$ concentrations in a pond in Eindhoven (the Netherlands) were similar in two consecutive years ( $t$ test; $t=0.241, P=0.816$ ) with an average of $38 \mu \mathrm{g}^{-1}$ recorded in the year without installation of the fountain, and $34 \mu \mathrm{g} 1^{-1}$ recorded in the year with the fountain installed (unpublished data). Mixing of shallow waters should be avoided, as sediment release of phosphorus may stimulate cyanobacteria rather than control them (Lürling et al., 2016a; Visser et al., 2016). In contrast, destratification or whole water column mixing in relatively deep water bodies (minimally 15-20 m) can effectively shift the phytoplankton community from cyanobacterial to green algal and diatom dominance (Visser et al., 2016). Mixing should enforce light limitation on the cyanobacteria (Newcombe et al., 2010). Intermittently operating the mixing devices to save energy is not recommended, as positively buoyant cyanobacteria can rapidly proliferate in periods without mixing (Jöhnk et al., 2008). Visser et al. (2016) listed a few preconditions for successful mixing: (1) mixing rate should be sufficiently high, (2) the mixing should be deep enough to bring light limitation to the cyanobacteria and (3) the distribution of aerators/mixers should be such that a large part of the lake is mixed. Costs for installing and operating mixing systems may be relatively large, for instance the costs of a new aeration system in the $1.3 \mathrm{~km}^{2}$ Lake Nieuwe Meer (the Netherlands) were valued at around $€ 750,000$ per $\mathrm{km}^{2}$ with annual operational costs of about $€ 25,000$, but these may easily offset loss of revenue from recreation (Visser et al., 2016).

Oil screen is another method to prevent inflow of surface accumulated cyanobacteria. The efficacy is limited when waves throw cyanobacteria over the screens, or when dispersed through the water column, cells/colonies will move underneath (Fig. 3D). A more efficient, but also more radical intervention is to fully dam off a part of the lake to protect for instance a swimming area. This was done in recreational area, De Gouden Ham, in 2008, where dams created a 5 ha enclosed area, while keeping out surface accumulated cyanobacteria (Lürling \& Van Oosterhout, 2013a). The construction of dams followed after an unsuccessful trial with ultrasound in 2007 (Kardinaal et al., 2008).

Use of low-energy ultrasound is not effective, because gas vesicles of cyanobacteria cannot be brought into resonance with the low frequencies ( 20 to $100 \mathrm{kHz}$ ) used (Leclerq et al., 2014; Lürling et al., 2016a) and no support for its supposed working mechanism has been found in the laboratory (Lürling \& Tolman, 2014) or field trials (Kardinaal et al., 2008; Lessmann \& Nixdorf, 2015). In a more recent field trial in Lake Zoetermeer (the Netherlands), four socalled ultrasound buoys were installed. The lake is being monitored at several sites (Noord Aa Strand, Noord Aa Speelvijver, and in the centre of the lake) by the Rijnland Regional Water Authority. The monitoring data do not provide evidence for a control of cyanobacteria (Fig. 4). Mean cyanobacterial 


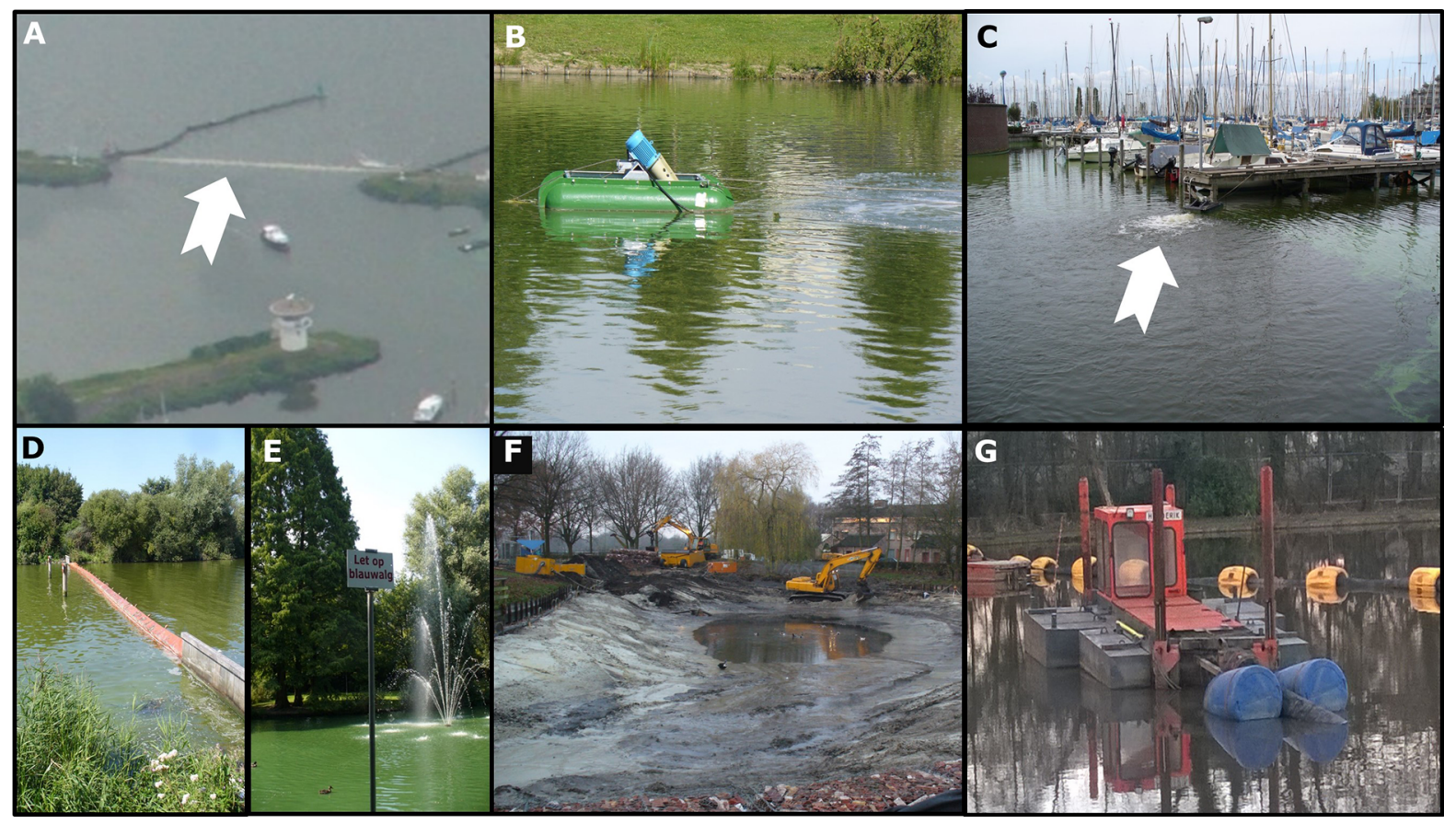

Fig. 3 Examples of several physical measures aimed at controlling cyanobacterial nuisance. A Bubble screen; B, C surface aerators; $\mathbf{D}$ oil screen; $\mathbf{E}$ fountain; $\mathbf{F}$ excavation; $\mathbf{G}$ dredging

biovolumes were similar between the two sites $\left(F_{1,7}=5.71 ; P=0.075\right)$, and similar in years, without and with ultrasound $\left(F_{1,7}=0.50 ; P=0.518\right)$. Likewise, mean cyanobacterial chlorophyll-a concentrations were similar at the two sites $\left(F_{1,7}=0.113\right.$; $P=0.753)$ and in years with and without ultrasound $\left(F_{1,7}=5.45 ; P=0.080\right)$. Also, total chlorophyll-a concentrations as determined from samples taken in the middle of the lake were similar (Welch's t test: $t=0.293 ; P=0.814$; Fig. 4). In contrast to lowenergy ultrasound, high-energy ultrasound is effective in killing cyanobacteria (Lürling \& Tolman, 2014), but it will also kill zooplankton in its power beam (Holm et al., 2008), while energy costs will be high for full-scale operations in the field and effective range may be limited.

Another physical method that is usually associated with relatively high costs is removal of nutrient rich sediment (Fig. 3F, G), which can be done by excavation or dredging (Cooke et al., 2005). Costs of dredging activities under jurisdiction of the National Water Authority in The Netherlands are expected be around $€ 332$ million over the period 2007-2027 (Ligtvoet et al., 2008). Although sediment removal is mostly aimed at deepening the water body to maintain water transport and allow shipping, it is also applied to improve water quality and to restore lost recreational amenities. Despite the regional water authorities, municipalities and lake owners implement dredging to improve water quality, most of these actions are performed without full reporting and effective monitoring (Lürling et al., 2020). Effects of dredging are not always as expected. For instance, in 1988, about $220,000 \mathrm{~m}^{3}$ sediment was removed from 47 ha in the 178 ha, shallow Lake Binnenschelde. The first year after dredging, the internal $P$ release was reduced from 4.1 to $6.8 \mathrm{mg} \mathrm{P} \mathrm{m}^{-2}$ day $^{-1}$ to $1.4 \mathrm{mg} \mathrm{P} \mathrm{m}^{-2}$ day $^{-1}$, but was back at the pre-treatment level the following year and no effects on water column $\mathrm{P}$ concentrations were observed (https://edepot.wur.nl/4702).

As an alternative to physically deepening a lake by removing the nutrient-enriched sediment, in deep, stratifying lakes, hypolimnetic withdrawal can be viewed as a successful, relatively low-cost restoration technique (Nürnberg, 2007, 2019). During late summer or early autumn, when the highest nutrient concentrations in the hypolimnion occur, discharge of hypolimnion water through a pipe (e.g. an Olszewski tube) on downstream water will remove those nutrients $\left(\mathrm{P}, \mathrm{NH}_{4}\right)$ from the lake. Care has to be 

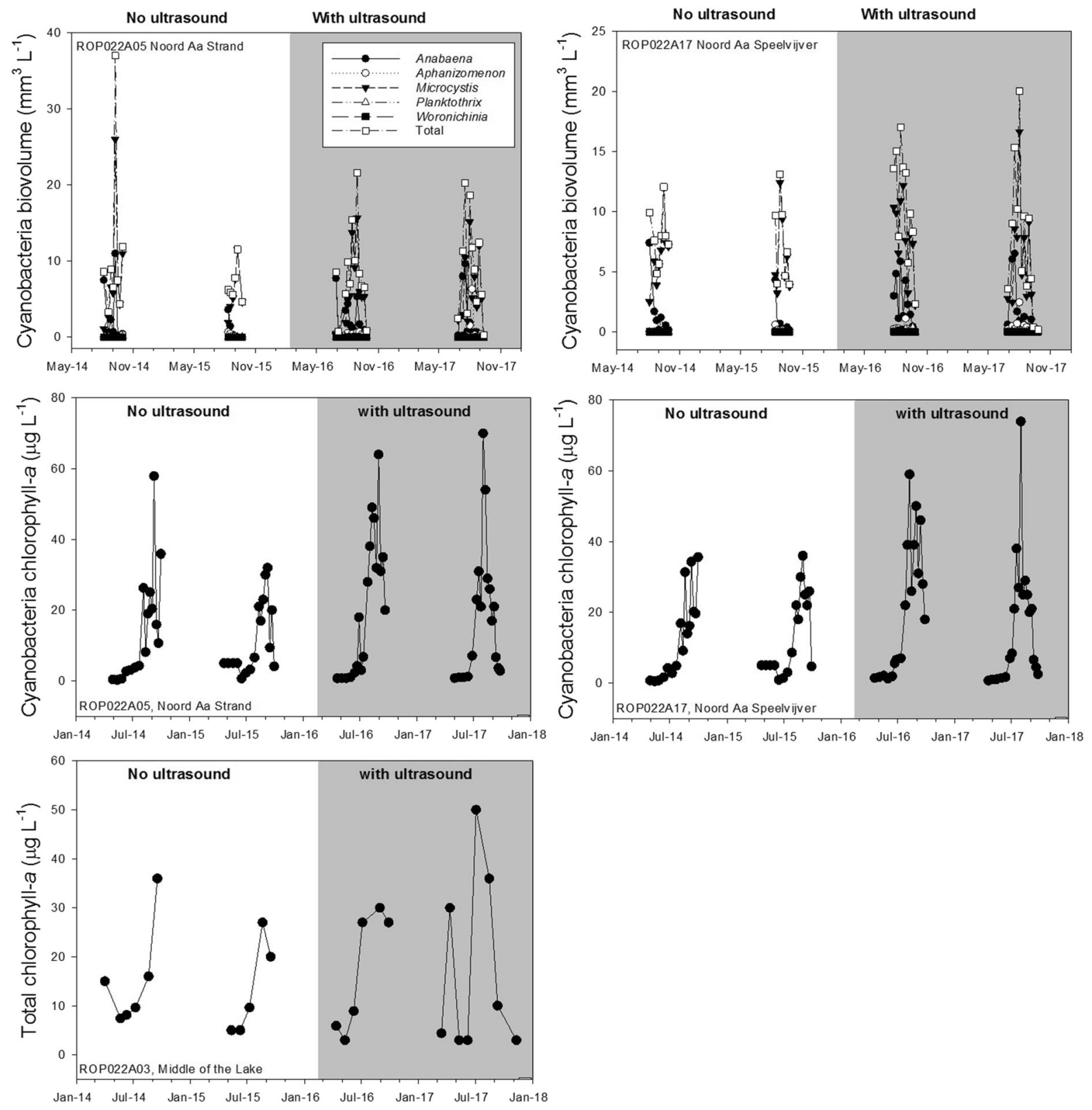

Fig. 4 Course of cyanobacterial biovolumes (top panels) and chlorophyll- $a$ concentrations (middle panels) at two swimming sites, as well as total chlorophyll- $a$ concentrations in the centre of Lake Zoetermeer (the Netherlands, bottom panel) during

2 years without (2014-2015) and 2 years with ultrasound treatment (2016-2017, indicated in grey). (Data provided by Rijnland Water Authority)

taken to prevent negative impacts on downstream water (Nürnberg, 2007, 2019). We are not aware of any hypolimnetic withdrawal case in the Netherlands.

Surface accumulated cyanobacteria may form thick scums in harbours or other near shore regions. Such scum can be removed by superficial skimming using a vacuum truck (Stroom \& Kardinaal, 2016). This has

been applied in the harbour of Almere-Haven in 2006, but was not effective, as cyanobacterial nuisance persisted for more than 2 months, as they could not effectively be stopped from accumulating in the harbour (Burger et al., 2007). Collected material was transported and processed in a wastewater treatment plant. To minimise transportation of high volumes of 
water, recent developments include systems that use natural coagulants and high-speed water-floc separation (http://waterned.com/movies-2/). No reports on actual case studies could be found. As with vacuum trucks, these systems only seem suited for relatively small water bodies and require access of the trucks to the shore.

Harvest of abundantly growing submerged macrophytes might reduce part of the nutrient load (Carpenter \& Adams, 1977), but efficacy in mitigating external- and internal nutrient load effects is highly variable (Cooke et al., 2005). Likewise, in the Netherlands, mixed results have been obtained using mowing boats, but efforts in monitoring the effects was generally poor (https://www.helpdeskwater.nl/ onderwerpen/water-ruimte/ecologie/meren/ingreepbiologie/waterplanten-0/). Moreover, harvesting carries the risk of complete loss of submerged vegetation, which can turn a lake into a turbid, algal dominated state (Van Nes et al., 2002).

\section{Chemical methods}

Chemical methods are used either to reduce the cyanobacterial biomass directly in water bodies via algaecides or coagulants or indirectly via strong decrease of nutrient availability hampering their proliferation (Jančula \& Maršálek, 2011).

Copper-based algaecides are relatively cheap and commonly used to control algal blooms in the USA (Bishop et al., 2018). They can be applied in small ponds or lakes (https://www.sepro.com/aquatics/ktea). Lake applications date back into the 1940s and include large lakes, such as the 8,112 ha Houghton Lake (Michigan) that annually received a few dozen tons of copper sulphate, with a maximum of 31 tons in 1977 (i.e. $\sim 1.5 \mathrm{~kg} \mathrm{Cu} \mathrm{ha}^{-1}$; Drevnik et al., 2009). Due to their non-specificity, copper-based products are no longer used in the Netherlands (Jančula \& Maršálek, 2011). At present, hydrogen peroxide is being tested on its efficacy and potential side effects; to avoid unwanted damage of non-target organisms. A maximum starting concentration of $5 \mathrm{mg} \mathrm{l}^{-1}$ is suggested, of which $2 \mathrm{mg} \mathrm{l}^{-1}$ of peroxide must remain at least for 5 hours in the water column (Matthijs et al., 2016). Hydrogen peroxide has been applied at least 20 times to Dutch surface waters varying from a small 0.2 ha pond to 100 ha lakes (https://www.stowa.nl/ sites/default/files/assets/DIGITALE\%20DIENSTEN/ Beating\%20the\%20Blues/FSctrl-biomassa_verwijder
en-waterstofperoxide_2019_NOL.pdf). Blooms can be avoided for almost an entire season after treatment (Matthijs et al., 2012). After hydrogen peroxide treatment in Lake Koetshuisplas (Veendam, the Netherlands), the lake experienced a period of 8 weeks, in which the cyanobacteria concentrations were below the threshold level for a swimming advisory, while in Lake Veerplas this period lasted only 3 weeks (Hazenoot et al., 2016). In other cases efficacy was less (https://www.ad.nl/delft/toch-weerblauwalg-in-water-delftse-hout-ondanks-maatregelen a08cd566/) or non-existent (Van de Graaf, 2016). Variability in efficacy depends upon type and density of cyanobacteria present, water chemistry and isolation of the water body. In addition to hydrogen peroxide, other oxidative agents can kill cyanobacteria, such as chlorine, ozone and potassium permanganate (Fan et al., 2013), yet these are not administered in Dutch surface waters.

Herbicides that cause inhibition of photosynthesis are also being used to counteract cyanobacterial blooms (Jančula \& Maršálek, 2011; Matthijs et al., 2016). There are, however, some issues with persistence and non-selectivity, causing, thus, toxicity towards non-target organisms, such as for 3-(3,4dichlorophenyl)-1,1-dimethylurea (commercially called Diuron) and its primary break-down product, 3,4-dichloroaniline (Jančula \& Maršálek, 2011). In general, green algae and diatoms are more sensitive to photosynthesis-inhibiting herbicides than cyanobacteria (Peterson et al., 1997; Fairchild et al., 1998) and, therewith, these herbicides might bring cyanobacteria into a superior competitive position (Lürling \& Roessink, 2006). The herbicide, Endothall, which interferes with RNA synthesis, and might be more effective towards cyanobacteria, has some major drawbacks as it is toxic for some zooplankton and is not effective in muddy waters (Jančula \& Maršálek, 2011). In their overview, Jančula \& Maršálek (2011) also listed several chemicals derived from natural compounds, but also indicated that the main limitation of such chemicals is their price. Lürling \& Van Oosterhout (2014) tested several plant extracts and amino acids, but rejected them as promising candidates for curative application in cyanobacterial bloom control, because of very limited effects that lasted only a few days.

All algaecides are developed with the specific aim of killing cyanobacteria cells. As a consequence, effective algacidal action can release cyanobacterial 
toxins into the water (Jančula \& Maršálek, 2011; Fan et al., 2014; Lürling et al., 2014). Such treatments should be avoided in drinking water reservoirs, as liberated toxins may remain present in the water for days (Jones \& Orr, 1994), unless toxins are fully eliminated by purification processes, such as filtration through activated carbon. However, in recreational water bodies, break-down and dilution may reduce dissolved cyanotoxins levels to safe levels within several days, without the need of any purification process (Matthijs et al., 2012). To our knowledge, no algaecides other than hydrogen peroxide are currently administered to Dutch surface waters.

An alternative to killing cells and reducing cyanobacterial biomass, is to aggregate them together using a coagulant and sink the aggregates out of the water column. Coagulation with alum is used in drinking water preparation (Drikas et al., 2001). In the USA, alum (aluminium sulphate) is commonly used to remove cyanobacteria from the water column and to adsorb phosphate (Cooke et al., 2005). In the Netherlands, however, use of aluminium salts and in particular alum is problematic. Potential toxicity issues, such as suffocation of fish (Poléo, 1995), and adding sulphate that could stimulate internal eutrophication (Smolders et al., 2006), make it virtually impossible to obtain a permit to apply alum in lakes, ponds and reservoirs in the Netherlands. Use of a low dose poly aluminium chloride (PAC; e.g. $1 \mathrm{mg} \mathrm{Al}^{-1}$ ) as a coagulant with a ballast is, however, permitted and was applied at field scale in 2008 in Lake Rauwbraken (Lürling \& Van Oosterhout, 2013b) and Lake De Kuil (in 2017). In Lake De Kuil, iron(III) chloride was applied as coagulant together with Phoslock ${ }^{\circledR}$ as ballast and P-fixative in 2009, which effectively reduced cyanobacterial biomass in the water column and reduced $\mathrm{P}$ released from the sediment (Waajen et al., 2016a). Phoslock ${ }^{\circledR}$ is a lanthanum-modified bentonite and a strong phosphate binder (Douglas, 2002). In the above mentioned cases, some of it served as ballast, while most of the applied Phoslock ${ }^{\circledR}$ was used to hamper sediment $\mathrm{P}$ release (Lürling \& Van Oosterhout, 2013b; Waajen et al., 2016a).

In case external inputs are relatively large, use of a coagulant and a ballast that is cheaper than Phoslock ${ }^{\circledR}$, such as a local soil might be an option to clear waters of cyanobacteria. This 'flock-and-sink' approach can be implemented with different coagulants and ballasts (Pan et al., 2006; Noyma et al., 2017). Ballast doses are between a few dozen to a few hundred $\mathrm{mg} \mathrm{l}^{-1}$; Pan et al. (2011) used approximately $25-31 \mathrm{mg}^{-1}$ (40-50 $\mathrm{g} \mathrm{m}^{-2}$ ) in an in situ experiment to effectively 'sink out' cyanobacteria from the water column in an isolated bay of Lake Taihu (China). It is, however, highly questionable if a 'flock-and-sink' approach is suitable for large, shallow wind-exposed lakes, such as Lake Taihu. Coagulation and sinking will not kill the entrapped cyanobacteria instantaneously, which in wind-exposed shallow lakes implies potentially rapid resuspension and recolonization of the over-lying water. Hence, a 'flock-and-sink' technique seems most suitable for stratifying lakes, where biomass can be transported effectively out of the epilimnion (Lürling \& van Oosterhout, 2013b).

The coagulant, chitosan, has been proposed as a biodegradable, environmentally friendly coagulant that provides an alternative to metal-based coagulants (Li \& Pan, 2013). Chitosan might, however, cause cell lysis with longer exposure (Mucci et al., 2017). Such a cell-damaging effect will reduce the possibility of recolonization of the water column by settled cyanobacteria that otherwise could survive for prolonged periods on the sediment (Reynolds et al., 1981). Moreover, cell lysis near the sediment allows decomposing bacteria to degrade any released cyanotoxins rapidly (Holst et al., 2003; Grützmacher et al., 2010; Li \& Pan, 2015).

Several chemicals can be used to immobilise phosphate with the aim of neutralising its bio-availability for cyanobacteria (Cooke et al., 2005; Lürling et al., 2020). Iron(III) chloride has been used for this purpose in the 18 ha, shallow Lake Groot Vogelenzang (Quaak et al., 1993). Despite the addition of 120 tons of $\mathrm{FeCl}_{3}\left(100 \mathrm{~g} \mathrm{Fe} \mathrm{m}^{-2}\right)$, water quality improvement was marginal and lasted only a few months (Quaak et al., 1993). In the shallow Lake Terra Nova (85 ha), adding 203 ton of $\mathrm{FeCl}_{3}\left(33 \mathrm{~g} \mathrm{Fe} \mathrm{m}^{-2}\right)$ to the lake over 1.5 years led to improved water quality during application, but TP and phytoplankton biomass already increased rapidly when dosing was stopped (Immers et al., 2015).

Phoslock $^{\circledR}$ has been used in more than 200 lakes worldwide, primarily as an agent to reduce the sediment $P$ release (Copetti et al., 2016). The treated lakes vary from pond size to 190 ha (http://www. phoslock.com.au/site/what-we-do/global-applications; Spears et al., 2016). In the Netherlands, Phoslock ${ }^{\circledR}$ has been applied to a shallow 1.8 ha swimming pond 
De Flaasbloem; a 5.0 ha lake that was dammed off from a larger lake at camp site Het Groene Eiland (Lürling \& van Oosterhout, 2013a); the $15 \mathrm{~m}$ deep, 2.6 ha swimming Lake Rauwbraken (Lürling \& van Oosterhout, 2013b); and the $9 \mathrm{~m}$ deep, 6.7 ha swimming Lake De Kuil (Waajen et al., 2016a). The small lake at Het Groene Eiland no longer exists, because it prevented boating, and is now part of a larger system. The official swimming lake, Lake De Kuil, had good water quality for 8 years following a first treatment that included Phoslock ${ }^{\circledR}$ (Waajen et al., 2016a). In 2017, however, a reapplication was required, due to ongoing diffuse external nutrient load and the influence of new raspberry farming activities next to the lake, where run-off contained almost $7 \mathrm{mg} \mathrm{P}^{-1}$, the total amount of nutrients discharge into the lake is still unknown.

A regular reapplication of a $\mathrm{P}$-fixative, such as Phoslock $^{\circledR}$, can be a strategy to effectively suppress cyanobacterial nuisance, as evidenced by the case of the German Bärensee (Epe et al., 2017). Ongoing diffuse inputs required the addition of P-fixative every three years to immobilise added $\mathrm{P}$ with an annual cost of $€ 5,000$, while revenues from open-bathing at the site was over $€ 300,000$ (Epe et al., 2017). Likewise, Lake Rauwbraken in the Netherlands suffered a fourmonth cyanobacterial bloom during the bathing season in 2007, which cost the municipality $€ 150,000$ (pers comm. alderman Jan Hamming, municipality Tilburg). The combined PAC-Phoslock ${ }^{\circledR}$ treatment cost $€ 50,000$, and has resulted in good quality swimming water until present. Nonetheless, ongoing diffuse nutrient inputs in this lake will also make the need for a reapplication inevitable; the longevity of the intervention has been estimated as 10-15 years (Van Oosterhout et al., submitted).

\section{Biological methods}

Biological methods are intended to change the ecosystem towards less favourable conditions for cyanobacteria. To this end, filter-feeding organisms can be added that forage on cyanobacteria (mussels, large-bodied zooplankton, filter-feeding fish, such as Tilapia or Silver Carp), fish can be removed that resuspend sediments, therewith, disabling macrophyte establishment, fish can be removed that feed on largebodied zooplankton, fish can be added that prey on zooplanktivorous fish, and submerged plants can be added (Triest et al., 2016).

The notion that benthivorous- and zooplanktivorous fish may play a dominant role in stabilising a turbid water state in shallow lakes has prompted a huge effort to restore shallow lakes by so-called 'biomanipulation'. Although removal of these fish led to improved water clarity in several lakes, most returned to a turbid state within 10 years (Søndergaard et al., 2007). Hence, repeated fish removal is required, because of rapid recruitment, but another important reason for the low success rate of biomanipulation is due to internal P load (Gulati \& Van Donk, 2002; Søndergaard et al., 2007). Nonetheless, it is evident that if fish stocks of bottom resuspending fish as high as hundreds or over a thousand kilogram per hectare are present (Waajen et al., 2014), a strong reduction is necessary to avoid uprooting of plants and to enable clear water for establishment of submerged macrophytes. To facilitate macrophyte reoccurrence active planting could be considered (Hilt et al., 2006). Reducing predation pressure on large-bodied Daphnia through the removal of zooplanktivorous fish may not be sufficient to control the overgrowth of all the cyanobacteria (Urrutia-Cordero et al., 2016). Adding piscivorous fish to reduce zooplanktivorous fish has yielded virtually no positive results (Triest et al., 2016). In a 10 ha constructed wetland adjacent to Lake Binnenschelde that has been created for reproduction and shelter of pike (Esox lucius) pike are not able to reach high density in the lake (https://edepot.wur.nl/ 4702).

Omnivorous filter-feeding fish (Tilapia, Oreochromis niloticus) have the potential to reduce cyanobacteria in eutrophic reservoirs (Torres et al., 2016). Those effects could be short-lived due to a high rate of defaecation of undigested cyanobacteria (Datta \& Jana, 1998). Overall, the effects of filter-feeding fish are limited (Triest et al., 2016) and to our knowledge no trials have been performed in the Netherlands.

Clear water can also be achieved through filtration by high biomass of dreissenids (Noordhuis et al., 2016). With nutrient load within the area between critical loads, strong grazing can shift a system from a turbid to a clear water state (Scheffer et al., 1993). In the 1,520 ha, shallow Lake Eem, however, the clear water created by high grazing rates of mussels is fragile as nutrient load is still high (Noordhuis et al., 2016). Hence, if mussels die or decline, a rapid 
reoccurrence of cyanobacteria is expected. Based on field observations an enclosure experiment was conducted that revealed dreissenids grown on special open structure crates could clear the water rapidly (Waajen et al., 2016b; Fig. 5). This experiment was upscaled to a 1 ha pond in the municipality of Breda (the Netherlands), in which 1,600 crates $(90 \times 45 \times 30 \mathrm{~cm}$ each $)$ were placed, but after 3 years of better water quality the experiment failed, because the dreissenids did not reproduce and gradually died over three years (G. Waajen, pers. comm.). Although the experiment was conducted under a legal permit, it was severely criticised, because the crates were covered with the invasive Quagga mussel, Dreissena rostriformis bugensis. Introducing Quagga mussels is no longer allowed, and permits will only be issued for providing hard substrate for mussels to settle on (G. Waajen, pers. comm.).
There are many formulations of so-called 'effective micro-organisms' (EM) that supposedly should compete with cyanobacteria for resources. Controlled experiments did not yield evidence for such claims (Lürling et al., 2009, 2010). Recently, the De Dommel Regional Water Authority (the Netherlands) treated an urban pond (vijver Jan van Galenweg, Vught) with 500 so-called 'EM-mud balls'. Also, this field trial yielded no evidence for successful control of cyanobacteria (Fig. 6).

\section{Evaluation of measures}

Implemented measures should be effective in mitigating eutrophication nuisance. It is not useful to spend taxpayers' money on actions that do not solve the problem or bring any relief. Given the lack of scientific evidence for effectiveness, the use of low-energy

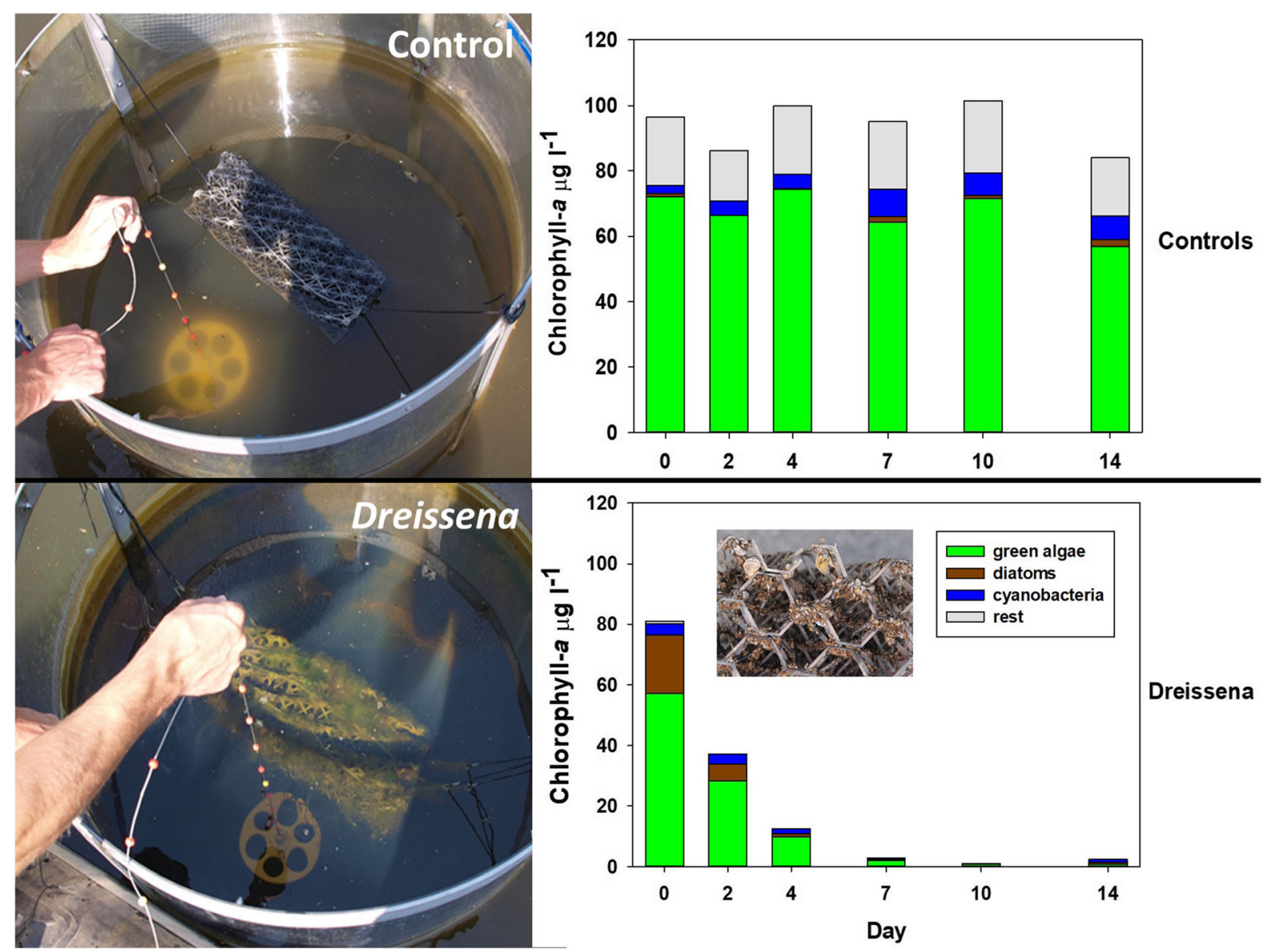

Fig. 5 Enclosure experiment with four enclosures that received an empty crate each and four that received a crate with dreissenids that cause strong reduction of the phytoplankton biomass (Waajen et al., 2016b; pictures G. Waajen) 


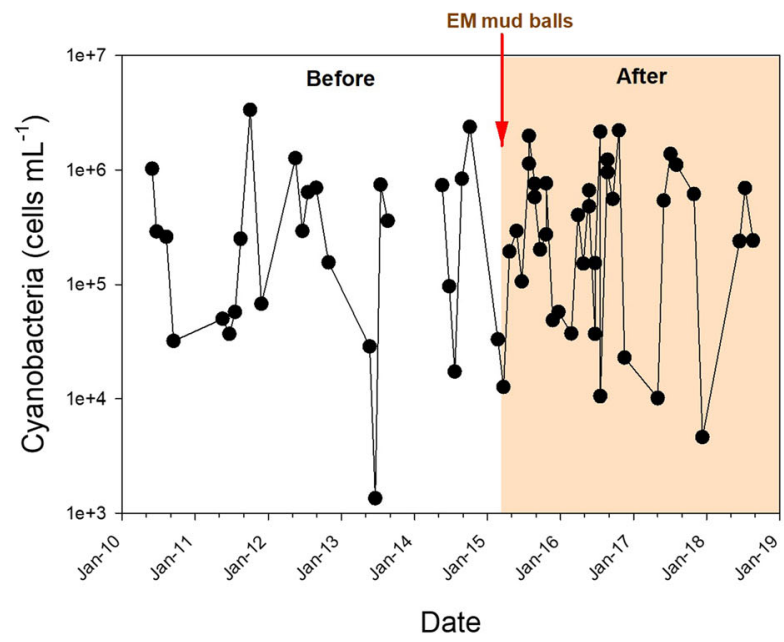

Fig. 6 Course of cyanobacteria cell counts (left panel, log scale) and total phosphorus concentrations (right panel) in an urban pond Jan van Galenweg (Vught, the Netherlands) that

ultrasound, 'effective micro-organism' formulations, and stocking with piscivorous or filter-feeding fish, can best be avoided (Table 1). In that respect, it is remarkable that the same water authority, which clearly demonstrated that 'EM-mud balls' were not effective (see Fig. 6), introduced 1,000 'EM balls' in another pond in April 2019. On July 22nd in the same year, a warning for cyanobacteria had to be issued for the pond. Obviously, 'EM-mud balls' do not prevent cyanobacterial growth. Physical measures aimed to reduce the inflow of buoyant cyanobacteria with oil screens, to reduce biomass build-up and surface accumulations (scums) with surface aerators might have rather low effects. On the other hand, effective measures may also come with consequences. For instance, damming of a part of a lake implies no access to the rest of the water body, which impairs boating, migration of fish and water exchange. Using high-energy ultrasound will kill everything in its power beam, but transmission in a lake will be rather limited. Hypolimnetic withdrawn water will be rich in nutrients and reduced compounds and preferably needs treatment before being discharged downstream. Copper-based algaecides and herbicides may exert negative effects on non-target biota (Jančula \& Maršálek, 2011). Hydrogen peroxide may do so too, unless properly dosed (Matthijs et al., 2012). Introducing dreissenids may meet resistance as it is viewed as an invasive species.

Adding a sediment phosphate binder to a water body with very low residence time that is being fed

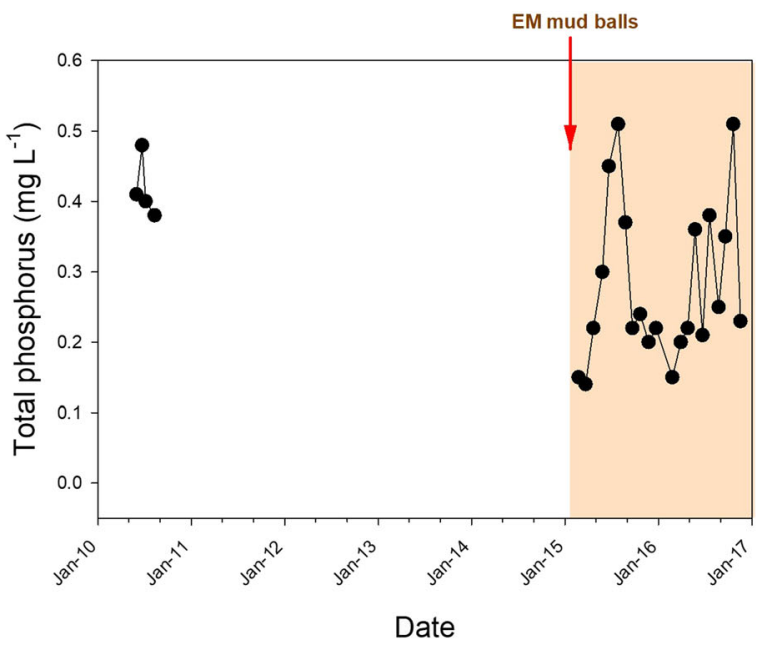

received 500 'EM-mud balls' (30th January, 2015, indicated by red arrow). (Data Water Authority De Dommel at HydroNet)

with phosphate rich inflow might only have short-lived effects. Measures that actually kill cyanobacteria (algaecides, hydrogen peroxide), remove their biomass from the water column effectively (coagulants and ballast) or strongly reduce phosphate availability (P-fixatives) seem to be most effective. Duration of a positive effect is, however, strongly influenced by subsequent nutrient input reduction. As algaecides and hydrogen peroxide will not remove nutrients, reoccurrence of cyanobacteria is inevitable. Likewise, lowering internal load, despite ongoing (diffuse) external load seems 'mopping with the tap still running', but might be the only option that water managers could have when political willingness to drastically reduce diffuse nutrient load is absent.

Reduction of cyanobacterial nuisance via lowering nutrient availability is rooted in the positive relationships between nutrient availability and cyanobacterial dominance (e.g. Watson et al., 1997; Rabalais, 2002). However, cyanobacterial blooms and surface scums may also occur in oligotrophic waters, such as NorthPatagonian lakes (Nimptsch et al., 2016) and, thus, are not always the result of eutrophication. Taking nutrient-directed measures is of little use in those lakes. Successful mitigation, therefore, requires a case-specific diagnosis, in which all aspects of the intended mitigation should be part of the system analysis. Such diagnosis will provide a guide to the most promising set of measures, which include efficiency, potential side effects, application 
Table 1 Overview of different measures and efficacy to counteract cyanobacterial nuisance directly via targeting the cyanobacteria or indirectly via reduction of nutrient availability

\begin{tabular}{|c|c|c|c|c|}
\hline Mitigation measures & Target & Efficacy & Duration & Treated lake area \\
\hline \multicolumn{5}{|l|}{ Physical methods } \\
\hline Air-bubble screen & Inflow cyanobacteria & Low & Only when in operation & Local, harbour entry ${ }^{\mathrm{a}}$ \\
\hline Surface aerators/mixers & Scums, odour & Low in shallow waters & Only when in operation & Local $^{\mathrm{a}}$ \\
\hline Fountains & Scums, odour & Low & Only when in operation & Local \\
\hline Oil screen & Inflow cyanobacteria & Low & Long term & Relative small scale ${ }^{a}$ \\
\hline Dam of a part of the lake & Inflow cyanobacteria & High, costly, affects lake integrity & Permanent & Shallow lakes \\
\hline Low-energy ultrasound & Cyanobacteria/algae & No effect & Only when in operation & n.a. \\
\hline High-energy ultrasound & Cyanobacteria/algae & High effect, kills everything, costly & Only when in operation & n.a. \\
\hline Excavation or dredging & Nutrients & Moderate/high effect, costly & 1 to $>10$ years $^{3}$ & $0.002^{\mathrm{b}}$ to $\sim 94 \mathrm{~km}^{2 \mathrm{c}}$ \\
\hline Hypolimnetic withdrawal & Nutrients & High, cheap, downstream effects & $1-30$ operation years $^{\mathrm{d}}$ & $0.02-14.9 \mathrm{~km}^{2 \mathrm{~d}}$ \\
\hline Superficial skimming & Scums & Low/moderate & Depends on inflow & Small, near shore ${ }^{a}$ \\
\hline Macrophyte harvest & Nutrients & Low/moderate & $1-4 \times$ per season & $100 \mathrm{ha}^{\mathrm{e}}$ \\
\hline \multicolumn{5}{|l|}{ Chemical methods } \\
\hline Copper-based algaecides & Cyanobacteria & High, legal permission issues & Short, needs repetitions & Ponds- $81 \mathrm{~km}^{2 \mathrm{f}}$ \\
\hline Hydrogen peroxide & Cyanobacteria & No-high, repeated dosing needed & $0-8$ weeks & Ponds- $1 \mathrm{~km}^{2}$ \\
\hline Herbicides & Cyanobacteria & High, potential side effects & Max. 1 season & Ponds, small lakes \\
\hline Coagulation & Cyanobacteria & High, repeated dosing needed & Max. 1 season & Small, deep lakes \\
\hline Phosphate binder & Nutrients (phosphate) & High, repeated dosing needed & $<1$ year to $>10$ years & Ponds-dozens $\mathrm{km}^{2 \mathrm{~b}}$ \\
\hline \multicolumn{5}{|l|}{ Biological methods } \\
\hline Macrophytes & Water clarity/nutrients & High, when able to grow & Long term & Littoral zone \\
\hline Bottom resuspending fish & Sediment, turbidity & High, when strongly reduced & $\sim 7-10$ years & $\mathrm{Up}$ to $26.5 \mathrm{~km}^{2 \mathrm{~g}}$ \\
\hline Piscivorous fish & Zooplankton-eating fish & No effect & In theory long term & 10 ha spawning site ${ }^{\mathrm{h}}$ \\
\hline Filter-feeding fish & Cyanobacteria/algae & No effect/very low effect & Short, nutrient release & Each lake \\
\hline Dreissenids & Cyanobacteria/algae & Variable results & Medium/long term & Hard substrates \\
\hline Effective micro-organisms & Cyanobacteria/nutrients & No effect & No effect & Ponds \\
\hline
\end{tabular}

${ }^{\mathrm{a}}$ Burger et al. (2007)

${ }^{\mathrm{b}}$ Lürling et al. (2020)

${ }^{\mathrm{c}}$ Zhong et al. (2018)

${ }^{\mathrm{d}}$ Nürnberg (2007)

e https://www.helpdeskwater.nl/onderwerpen/water-ruimte/ecologie/meren/ingreep-biologie/waterplanten-0/

${ }^{\mathrm{f}}$ Drevnick et al. (2009)

${ }^{\mathrm{g}}$ Meijer (2000)

${ }^{\mathrm{h}}$ https://edepot.wur.nl/4702

possibilities and costs of the chosen mitigation measures (Lürling et al., 2016b).

\section{Combination of measures}

Decades ago, it was already recognised that internal loading in lakes frustrated the restoration efforts from external load control and that additional measures would be needed (Van Liere \& Gulati, 1992). One of the main conclusions from an international meeting held in Amsterdam in the Netherlands in 1989 was that: "tailor-made restoration programmes, including 'biomanipulation', for particular lakes are necessary to tackle the eutrophication problems in shallow lakes" (Hosper \& Jagtman, 1990). It prompted biomanipulation interventions in the Netherlands, yet the necessity of a thorough lake system analysis prior to implementation of 'tailor-made' measures (Van Liere \& Gulati, 1992) was not always followed, or decisions took many years. For instance, Lake Breukeleveen, did not clear up after external load control, and also no 
improved water quality occurred after biomanipulation (Van Donk et al., 1994). Compartment experiments yielded insights that not only fish biomass needed to be reduced, but that wind/wave actions should be diminished to prevent sediment resuspension and to allow rooting of macrophytes (Van Donk et al., 1994). The required interventions are now scheduled between 2019 and 2026 (PNH, 2017).

In their review on the achievements of restoration work in the Dutch lakes, Gulati and Van Donk (2002) concluded that there are probably more examples of failures than of successes of restoration attempts using 'biomanipulation', where the failures were mostly caused by inadequate or no in-lake nutrient loadings (Gulati \& Van Donk, 2002), and consequently, result in inadequate system analysis and 'copy-paste' of measures. This by no means implies that biomanipulation is an ineffective measure that should be abandoned. The typical water turbidity-nutrient loading hysteresis plot (see Fig. 2) already illustrates the necessity, next to nutrient load reduction, of actions to clear the water column, such that submerged macrophytes can establish sufficient biomass to stabilise a clear water state (Scheffer et al., 1993; Gulati \& Van Donk, 2002). The large number of 'biomanipulation' trials in the Netherlands are based on this relationship. In as much as during the process of eutrophication, planktivorous- and benthivorous fish biomass will have increased, driving the zooplankton community structure to small-bodied, less efficient grazers, increasing phytoplankton biomass and turbidity, which lead to a loss of macrophytes (Moss, 2010), ecosystem restructuring should be part of the rehabilitation package.

An example of a successful package of measures is given by Pond Heesch (the Netherlands). For many years, this pond was suffering from massive cyanobacterial blooms and surface scums, with high cyanobacteria toxins concentrations (Waajen et al., 2014). The pond was packed with fish $\left(1,400 \mathrm{~kg} \mathrm{ha}^{-1}\right)$, of which $85 \%$ comprised of bottom-dwelling carp (Waajen et al., 2014). Such a large amount of fish will keep the water turbid (Roozen et al., 2007). In Winter 2009/2010, the Aa \& Maas Regional Water Authority executed the following package of measures: Fish were removed, the pond was pumped dry and sediment excavated, a sewer overflow was dismantled, trees were harvested and pruned to prevent leaves falling in the pond, soft banks were created, macrophytes planted, citizens were informed about effects of feeding ducks and fish. This intervention that cost $€$ 17,660 , for $678 \mathrm{~m}^{3}$ sediment removal and $€ 2,450$, for fish stock manipulation led to strongly improved water quality; before intervention, cyanobacterial chlorophyll-a concentration was around an average $140 \mu \mathrm{g}$ $1^{-1}$, while this was $1.6 \mu \mathrm{g} \mathrm{l}^{-1}$ over the 9 years after the intervention (Fig. 7). Such drastic combined measures are only feasible in relatively small surface waters.

The vast majority of waters where citizens experienced cyanobacterial nuisance (see Fig. 1) are relatively small urban waters (Waajen et al., 2014). These are not included in regular monitoring programmes, such as in the Water Framework Directive (WFD) water quality monitoring that excludes lakes smaller than 50 ha (EC, 2012). Not including small water bodies in regular monitoring programmes is a huge omission. Worldwide, approximately $95 \%$ of the total 117 million lakes are smaller than 50 ha (Verpoorter et al., 2014). Those small waters are often easier to restore than large lakes at relatively low costs, as exemplified by the case of Heesch Pond (Fig. 7). Municipalities already allocate taxes for maintenance of public space (roads, parks, playgrounds, mowing ditches), they could also start allocating some of it for maintenance of their urban waters. Heesch Pond has maintained an excellent water quality for 10 years, with an intervention cost of around $€ 2,000$ per annum. Likewise, the intervention in Lake Rauwbraken (Lürling \& Van Oosterhout, 2013b) has provided more than 10 years good swimming water and some maintenance every 10 years would ensure recreation possibilities at much lower costs than closure due to toxic blooms (Van Oosterhout et al., submitted), as has been exemplified already elsewhere (Epe et al., 2017).

\section{In-lake measures are inevitable}

The root cause of most cyanobacterial blooms, i.e. fertilisation of surface water, has already been known for many decades (Edmondson et al., 1956; Parma, 1980). Reduction of external nutrient inputs is a straightforward initial management step (e.g. Hamilton et al., 2016; Paerl et al., 2016; Huisman et al., 2018), but it is clearly not enough, given that pressure is increasing on inland waters from worldwide expansion of cyanobacterial blooms (O'Neil et al., 2012; Paerl \& Paul, 2012; Huisman et al., 2018). Only 
very few water bodies cleared up following external point load control alone, such as Lake Washington (Edmondson, 1970). Diffuse nutrient pollution and legacies are maintaining the undesired water quality in most lakes. Watershed or catchment activities aimed at reducing the nutrient leakage to surface waters, such as best management practices, do not seem so effective (Osgood, 2017), or are limited by time lags of decades to centuries between the initiation of a management interventions and the estimated response (Rissman \& Carpenter, 2015; Goyette et al., 2018). In the Netherlands, point source pollution has been tackled, and even if ongoing diffuse pollution from massive agricultural industry could be stopped completely, the time needed for leaching out the accumulated $\mathrm{P}$ in the watershed may reach centuries in agricultural areas (Goyette et al., 2018). This could stimulate authorities to drastically reduce $\mathrm{N}$ inputs, as denitrification losses can be substantial (Scott et al., 2019). The current reality, however, is that the Netherlands is blanketed by oxidised- and reduced $\mathrm{N}$ species. The latter primarily originates from agricultural activities, and in recent years, the national average deposition showed a $20 \%$ increase from around 1,050 mol per hectare in 2015 to $1,260 \mathrm{~mol}$ per hectare in 2018, while in regions with intense animal farming deposition reaches 4,000 mol $\mathrm{N}$ per hectare per year (CLO, 2019). Simply 'sitting it out' is not a viable option, as water is a vital resource and good surface water quality is essential for preparing drinking water, irrigation, aquaculture, industry, recreation and amenity. Consequently, in-lake interventions are a logical step to bring surface waters closer to the desired state of being devoid of cyanobacterial blooms. In case of diffuse load, geoengineering techniques that can rapidly remove cyanobacteria out of the water column and/or permanently immobilise phosphate in the water column and in the sediment may be used (Lürling et al., 2016b). Similar conclusions have been drawn for the USA, where watershed best management practices are largely insufficient to control diffuse $\mathrm{P}$ influx, while mitigating internal $\mathrm{P}$ is much cheaper, with quicker results at cheaper costs (Huser et al., 2016; Osgood, 2017). In-lake measures are important for speeding-up recovery in water bodies, where external nutrient loading has been reduced, or where external load is low, but over decades resulted in internal load orders

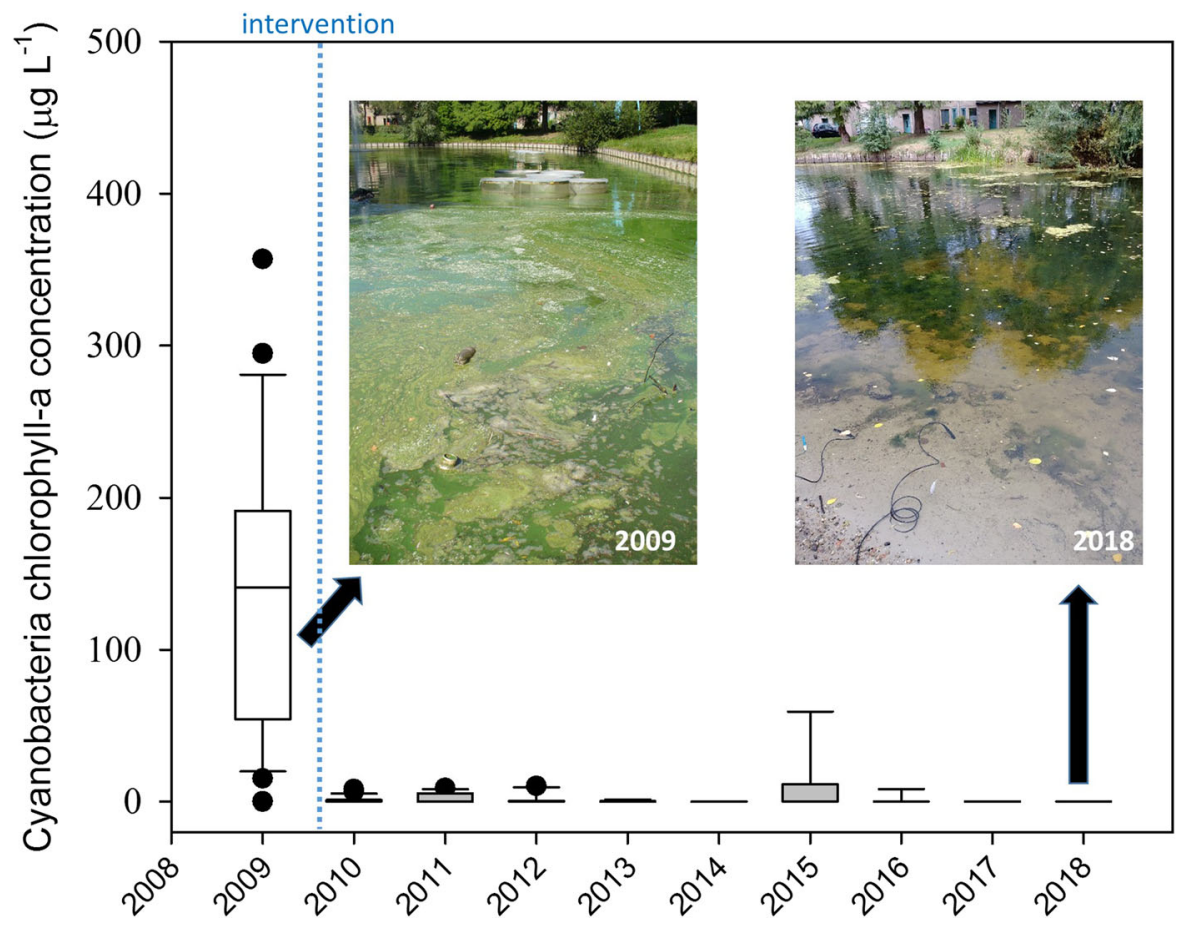

Fig. 7 Box plots of annual cyanobacterial chlorophyll- $a$ concentrations $\left(\mu \mathrm{g}^{-1}\right)$ in Pond Heesch before and after a whole package of restoration measures 
of magnitude larger than the inflow. As outlined previously, ecosystem changes will have occurred (Moss, 2010) that may need in-lake actions (e.g. carp removal) and nutrient legacies in the lake bed may be of concern as these can delay recovery strongly (Ryding \& Forsberg, 1976; Sharpley et al., 2013).

In many countries, however, even point source nutrient pollution is not being tackled adequately. The extremely low share of wastewater being treated properly worldwide is worrying (WWAP, 2017). High investments will be needed to improve sewerage coverage and sewage treatment (van Loosdrecht \& Brdjanovic, 2014), which will take years to be implemented. Meanwhile, population growth increases the demand for safe and clean water. For instance, Lake Koka Reservoir (Ethiopia) has become highly eutrophic suffering from annually reoccurring toxic cyanobacterial blooms that pose a serious risk to the local inhabitants, who use it as it as their sole drinking water source (Major et al., 2018). Therefore, within-system interventions to recurrently mitigate eutrophication nuisance and to control cyanobacterial blooms seem inevitable, because they allow bridging the time until proper nutrient control measures from wastewater have been realised. Here, coagulants and P-fixatives can be considered in polluted streams (e.g. Mason et al., 2005; Pilgrim \& Brezonik, 2005), but also interventions in receiving lakes and reservoirs with coagulants and local soil as ballast (e.g. Noyma et al., 2016) or algaecides such as hydrogen peroxide (Matthijs et al., 2012) may be considered depending on the outcomes of system analysis. Hence, even in water bodies receiving high external nutrient loadings there is no reason not to counteract developing cyanobacterial blooms as an "end of the pipe fix" (Lürling et al., 2016a; Matthijs et al., 2016), when such action may strongly reduce danger for those who rely on the water as their sole source of drinking water, because it will bring real-time relief allowing more structural measures to be implemented.

Repeated interventions are nothing new, for example in the Dutch swimming lake, Delftse Hout, in 2015, 2016, 2018 and 2019, hydrogen peroxide has been used to sweep the water clear of nuisance cyanobacteria (https://www.hhdelfland.nl/actueel/ nieuws/delfland-bestrijdt-blauwalg-delftse-hout-plastijdelijk-dicht, accessed 29th July 2019). In Germany, regular additions of a P-fixative to the Bärensee near Frankfurt am Main ensured swimming water quality
(Epe et al., 2017). Considering the political reality, diffuse pollution will not be stopped rapidly in the Netherlands. Diffuse loads, and certainly for N, will continue, thus, regular interventions will be required. Such interventions need to be anchored in site-specific diagnostics (Cooke et al., 2005; Lürling et al., 2016b; Stroom \& Kardinaal, 2016).

More than 25 years ago it was already emphasised that "each lake has to be studied before restoration measures can be applied" (Van Liere \& Gulati, 1992), yet these words still need to be repeated. Water authorities, municipalities and lake managers should spend more energy in such proper diagnoses than in wasting taxpayers' money by blindly believing the magic claims made by 'quick-fix' advocates. In addition, decision-makers should take the consequences of diffuse nutrient pollution for surface water quality into account.

Acknowledgements We cordially thank Rijnland Regional Water Authority for providing their monitoring data. The National Water Authority (Rijkswaterstaat) is thanked for granting participation in an inspection flight. Dr Guido Waajen (Regional Water Authority Brabantse Delta) is thanked for sharing pictures and data. Dr. G.N. Nürnberg and an anonymous reviewer are thanked for constructive comments on the manuscript. Sara Sharpe of 'Wageningen in'to Languages' is warmly thanked for linguistic corrections of the manuscript.

Open Access This article is licensed under a Creative Commons Attribution 4.0 International License, which permits use, sharing, adaptation, distribution and reproduction in any medium or format, as long as you give appropriate credit to the original author(s) and the source, provide a link to the Creative Commons licence, and indicate if changes were made. The images or other third party material in this article are included in the article's Creative Commons licence, unless indicated otherwise in a credit line to the material. If material is not included in the article's Creative Commons licence and your intended use is not permitted by statutory regulation or exceeds the permitted use, you will need to obtain permission directly from the copyright holder. To view a copy of this licence, visit http://creativecommons.org/licenses/by/4.0/.

\section{References}

Beaulieu, J. J., T. DelSontro \& J. A. Downing, 2019. Eutrophication will increase methane emissions from lakes and impoundments during the 21 st century. Nature Communications 10: 1375.

Bishop, W. M., R. J. Richardson \& B. E. Willis, 2018. Comparison of partitioning and efficacy between copper 
algaecide formulations: refining the critical burden concept. Water Air Soil Pollution 229: 300.

Burger, D., H. Los \& S. Groot, 2007. Bestrijding van blauwalgen in de havenkom Almere-Haven. WL Delft Hydraulics, Report Q4328.00 (in Dutch).

Carpenter, S. R. \& M. S. Adams, 1977. The macrophyte tissue nutrient pool of a hardwater eutrophic lake: implications for macrophyte harvesting. Aquatic Botany 3: 239-255.

CBS, 2018. Belasting van het oppervlaktewater met vermestende stoffen, 1990-2016. https://www.clo.nl/indicatoren/ n10192-belasting-van-oppervlaktewater-met-vermestendestoffen.

CBS, 2019a. Agricultural export value over 90 bn euros in 2018. https://www.cbs.nl/en-gb/news/2019/03/agriculturalexport-value-over-90-bn-euros-in-2018.

CBS, 2019b. Stroomschema voor stikstof en fosfor in de landbouw, 2017. https://www.clo.nl/indicatoren/n10094stroomschema-stikstof-en-fosfor.

CBS, 2019c. Nutriëntenoverschotten in de landbouw, 1970-2017. https://www.clo.nl/indicatoren/n10096stikstof-en-fosforoverschotten-in-de-landbouw.

CBS, PBL, Wageningen UR, 2012. Kwaliteit oppervlaktewater, 2009 (indicator 1438 , version 04, 5 December 2012), CBS, The Hague; Planbureau voor de Leefomgeving, The Hague/Bilthoven en Wageningen UR, Wageningen. [available at: www.compendiumvoordeleefomgeving.nl/ indicatoren/nl1438-Kwaliteitoppervlaktewater-KRW. html?i=2-76].

Chorus, I., I. R. Falconer, H. J. Salas \& J. Bartram, 2000. Health risks caused by freshwater cyanobacteria in recreational waters. Journal of Toxicology and Environmental Health: Part B 3: 323-347.

CLO, Compendium voor de Leefomgeving, 2018. Zuivering van stedelijk afvalwater: stikstof en fosfor, 1981-2016 (in Dutch) https://www.clo.nl/indicatoren/n1015220zuivering-van-stedelijk-afvalwater-stikstof-en-fosfor.

CLO, Compendium voor de Leefomgeving, 2019. Stikstofdepositie, 1990-2018 (in Dutch). https://www.clo.nl/ indicatoren/nl0189-stikstofdepositie.

COV, 2019. https://www.cov.nl/sector-in-cijfers.

Cooke, G. D., E. B. Welch, S. Peterson \& S. A. Nichols, 2005. Restoration and Management of Lakes and Reservoirs. CRC Press, Boca Raton.

Copetti, D., K. Finsterle, L. Marziali, F. Stefani, G. Tartari, G. Douglas, K. Reitzel, B. M. Spears, I. J. Winfield, G. Crosa, P. D'Haese, S. Yasseri \& M. Lürling, 2016. Eutrophication management in surface waters using lanthanum modified bentonite: a review. Water Research 97: 162-174.

Cordell, D., J.-O. Drangert \& S. White, 2009. The story of phosphorus: global food security and food for thought. Global Environmental Change 19(2): 292-305.

Datta(Saha), S. \& B. B. Jana, 1998. Control of bloom in a tropical lake: grazing efficiency of some herbivorous fishes. Journal of Fish Biology 53: 12-24.

Drevnick, P. E., R. R. Otter, P. R. Gorski, D. T. Long, D. E. Canfield \& J. T. Oris, 2009. Lake-specific responses in sedimentary sulphur, after additions of copper sulphate to lakes in Michigan, USA. Lakes \& Reservoirs: Research and Management 14: 193-201.

Drikas, M., C. W. K. Chow, J. House \& M. D. Burch, 2001. Using coagulation, and settling to remove toxic cyanobacteria. Journal of the American Water Works Association 93: 100-111.

Douglas, G. B. 2002. US patent 6350383: remediation material and remediation process for sediments.

Downing, J. A., 2014. Limnology and oceanography: two estranged twins reuniting by global change. Inland Waters 4: 215-232.

EC, European Commission, 2012. Country-specific assessments for EU Member States and Norway (volumes 3-30), SWD(2012)379, volume 22. http://ec.europa.eu/ environment/water/water-framework/pdf/3rd_report/ CWD-2012-379_EN-Vol3_NL.pdf.

Edmondson, W. T., 1970. Phosphorus, nitrogen, and algae in Lake Washington after diversion of sewage. Science 169(3946): 690-691.

Edmondson, W. T., G. C. Anderson \& D. R. Peterson, 1956. Artificial Eutrophication of Lake Washington. Limnology Oceanography 1(1): 47-53.

EEA, European Environment Agency, 2018. Ecological status of surface water bodies. https://www.eea.europa.eu/ themes/water/european-waters/water-quality-and-waterassessment/water-assessments/ecological-status-ofsurface-water-bodies.

Epe, T. S., K. Finsterle \& S. Yasseri, 2017. Nine years of phosphorus management with lanthanum modified bentonite (Phoslock) in a eutrophic, shallow swimming lake in Germany. Lake and Reservoir Management 33: 119-129.

EU, European Union, 2013. Seventh Report on the Implementation of the Urban Waste Water Treatment Directive (91/ 271/EEC), COM (2013) 574 final.

EU, European Union, 2017. The EU Environmental Implementation Review Country Report: The Netherlands, SWD (2017) 52 final.

Fairchild, J. F., D. H. Ruessler \& A. R. Carlson, 1998. Comparative sensitivity of five species of macrophytes and six species of algae to atrazine, metribuzin, alachlor, and metolachlor. Environmental Toxicology and Chemistry 17: $1830-1834$.

Fan, J., L. Ho, P. Hobson \& J. Brookes, 2013. Evaluating the effectiveness of copper sulphate, chlorine, potassium permanganate, hydrogen peroxide and ozone on cyanobacterial cell integrity. Water Research 47: 5153-5164.

Fan, J., P. Hobson, L. Ho, R. Daly \& J. Brookes, 2014. The effects of various control and water treatment processes on the membrane integrity and toxin fate of cyanobacteria. Journal of Hazardous Materials 264: 313-322.

Forsberg, C., 1998. Which policies can stop large scale eutrophication? Water Science and Technology 37(3): 193-201.

Goyette, J.-O., E. M. Bennett \& R. Maranger, 2018. Low buffering capacity and slow recovery of anthropogenic phosphorus pollution in watersheds. Nature Geoscience 11: 921-925.

Grützmacher, G., G. Wessel, S. Klitzke \& I. Chorus, 2010. Microcystin elimination during sediment contact. Environmental Science \& Technology 44: 657-662.

Gulati, R. D. \& E. van Donk, 2002. Lakes in the Netherlands, their origin, eutrophication and restoration: state-of-the-art review. Hydrobiologia 478: 73-106.

Hamilton, D. P., N. Salmaso \& H. W. Paerl, 2016. Mitigating harmful cyanobacterial blooms: strategies for control of 
nitrogen and phosphorus loads. Aquatic Ecology 50: 351-366.

Hazenoot, C., B. Reeze, H. C. P. Matthijs \& J. Meeuse, 2016. Effectiviteit bestrijding blauwalgen met waterstofperoxide. $\mathrm{H} 2 \mathrm{O} 21$ : 31-34.

Hilt, S., E. M. Gross, M. Hupfer, H. Morscheid, J. Mählmann, A. Melzer, J. Poltz, S. Sandrock, E.-M. Scharf, S. Schneider \& K. vande Weyer, 2006. Restoration of submerged vegetation in shallow eutrophic lakes: a guideline and state of the art in Germany. Limnologica 36: 155-171.

Holm, E. R., D. M. Stamper, R. A. Brizzolara, L. Barnes, N. Deamer \& J. M. Burkholder, 2008. Sonication of bacteria, phytoplankton and zooplankton: application to treatment of ballast water. Marine Pollution Bulletin 56: 1201-1208.

Holst, T., N. O. G. Jørgensen, C. Jørgensen \& A. Johansen, 2003. Degradation of microcystin in sediments at oxic and anoxic, denitrifying conditions. Water Research 37: 4748-4760.

Hosper, S. H. \& E. Jagtman, 1990. Biomanipulation additional to nutrient control for restoration of shallow lakes in The Netherlands. Hydrobiologia 200(201): 523-534.

Huisman, J., G. A. Codd, H. W. Paerl, B. W. Ibelings, J. M. H. Verspagen \& P. M. Visser, 2018. Cyanobacterial blooms. Nature Reviews 16: 471-483.

Huser, B. J., M. Futter, J. T. Lee \& M. Pernie, 2016. In-lake measures for phosphorus control: the most feasible and cost-effective solution for long-term management of water quality in urban lakes. Water Research 97: 142-152.

Immers, A. K., E. S. Bakker, E. Van Donk, S. A. J. Declerck, G. N. J. Ter Heerdt \& J. J. M. Geurts, 2015. Fighting internal phosphorus loading: an evaluation of the large scale application of gradual Fe-addition to a shallow peat lake. Ecological Engineering 83: 78-89.

Jančula, D. \& B. Maršálek, 2011. Critical review of actually available chemical compounds for prevention and management of cyanobacterial blooms. Chemosphere 85(9): 1415-1422.

Janse, J. H., M. Scheffer, L. Lijklema, L. Van Liere, J. S. Sloot \& W. M. Mooij, 2010. Estimating the critical phosphorus loading of shallow lakes with the ecosystem model PCLake: sensitivity, calibration and uncertainty. Ecological Modelling 221: 654-665.

Jeppesen, E., B. Kronvang, M. Meerhoff, M. Søndergaard, K. M. Hansen, H. E. Andersen, T. L. Lauridsen, L. Liboriussen, M. Beklioglu, A. Özen \& J. E. Olesen, 2009. Climate change effects on runoff, catchment phosphorus loading and lake ecological state, and potential adaptations. Journal of Environmental Quality 38(5): 1930-1941.

Jöhnk, K. D., J. Huisman, J. Sharples, B. Sommeijer, P. M. Visser \& J. M. Stroom, 2008. Summer heatwaves promote blooms of harmful cyanobacteria. Global Change Biology 14: 495-512.

Jones, G. J. \& P. T. Orr, 1994. Release and degradation of microcystin following algicide treatment of a Microcystis aeruginosa bloom in a recreational lake, as determined by HPLC and protein phosphatase inhibition assay. Water Research 28(4): 871-876.

Jukema, G. D., P. Ramaekers, P. Berkhout, 2020. De Nederlandse agrarische sector in internationaal verband. Wageningen/Heerlen/Den Haag, Wageningen Economic
Research en Centraal Bureau voor de Statistiek, Rapport 2020-001. (in Dutch). https://doi.org/10.18174/511255.

Kardinaal, E., M. De Haan \& H. Ruiter, 2008. Maatregelen ter voorkoming blauwalgen werken onvoldoende. $\mathrm{H} 2 \mathrm{O}$ 7: 4-7.

Leclerq, D. J. J., C. Q. Howard, P. Hobson, S. Dickson, A. C. Zander \& M. Burch, 2014. Controlling cyanobacteria with ultrasound. Inter-noise 2014: 1-10.

Lessmann, D., \& B. Nixdorf, 2015. Use of ultrasound of the reduction and control of cyanobacteria and phytoplankton in water bodies and technical processes of water treatment-subproject 2. Brandenburg University of Technology, Report 02WQ1197.

Li, L. \& G. Pan, 2013. A universal method for flocculating harmful algal blooms in marine and fresh waters using modified sand. Environmental Science \& Technology 47(9): 4555-4562.

Li, H. \& G. Pan, 2015. Simultaneous removal of harmful algal blooms and microcystins using microorganism-and chitosan-modified local soil. Environmental Science \& Technology 49(10): 6249-6256.

Ligtvoet, W., G. Beugelink, C. Brink, R. Franken \& F. Kragt, 2008. Kwaliteit voor Later. Ex ante evaluatie Kaderrichtlijn Water. PBL publicatienummer 50014001/200, ISBN: 978-90-6960-203-5.

Lürling, M. \& I. Roessink, 2006. On the way to cyanobacterial blooms: impact of the herbicide metribuzin on the competition between a green alga (Scenedesmus) and a cyanobacterium (Microcystis). Chemosphere 65(4): 618-626.

Lürling, M. \& Y. Tolman, 2014. Beating the blues: is there any music in fighting cyanobacteria with ultrasound? Water Research 66: 361-373.

Lürling, M. \& F. van Oosterhout, 2013a. Case study on the efficacy of a lanthanum-enriched clay (Phoslock ${ }^{\circledR}$ ) in controlling eutrophication in Lake Het Groene Eiland (The Netherlands). Hydrobiologia 710: 253-263.

Lürling, M. \& F. van Oosterhout, 2013b. Controlling eutrophication by combined bloom precipitation and sediment phosphorus inactivation. Water Research 47(17): 6527-6537.

Lürling, M. \& F. van Oosterhout, 2014. Effect of selected plant extracts and D- and L-lysine on the cyanobacterium $\mathrm{Mi}$ crocystis aeruginosa. Water 6: 1807-1825.

Lürling, M., Y. Tolman \& M. Euwe, 2009. Mitigating cyanobacterial blooms: how effective are 'effective microorganisms'? Lakes and Reservoirs: Research and Management 14: 353-363.

Lürling, M., Y. Tolman \& F. van Oosterhout, 2010. Cyanobacteria blooms cannot be controlled by Effective Microorganisms $\left(\mathrm{EM}^{\circledR}\right)$ from mud- or Bokashi-balls. Hydrobiologia 646: 133-143.

Lürling, M., D. Meng \& E. J. Faassen, 2014. Effects of hydrogen peroxide and ultrasound on biomass reduction and toxin release in the cyanobacterium, Microcystis aeruginosa. Toxins 6: 3260-3280.

Lürling, M., G. Waajen \& L. N. de Senerpont Domis, 2016a. Evaluation of several end-of-pipe measures proposed to control cyanobacteria. Aquatic Ecology 50: 499-519.

Lürling, M., E. Mackay, K. Reitzel \& B. M. Spears, 2016 b. Editorial: a critical perspective on geo-engineering for 
eutrophication management in lakes. Water Research 97: $1-10$.

Lürling, M., A. J. P. Smolders \& G. D. Douglas, 2020. Methods for the management of internal loading. In Steinman, A. D. \& B. M. Spears (eds), Internal Phosphorus Loading of Lakes: Causes, Case Studies, and Management. J. Ross Publishing, Plantation, FL, pp. 77-107.

Major, Y., D. Kifle, L. Spoof \& J. Meriluoto, 2018. Cyanobacteria and microcystins in Koka reservoir (Ethiopia). Environmental Science and Pollution Research 25: 26861-26873.

Mason, L. B., C. Amrhein, C. C. Goodson, M. R. Matsumoto \& M. A. Anderson, 2005. Reducing sediment and phosphorus in tributary waters with alum and polyacrylamide. Journal of Environmental Quality 34: 1998-2004.

Matthijs, H. C. P., P. M. Visser, B. Reeze, J. Meeuse, P. C. Slot, G. Wijn, R. Talens \& J. Huisman, 2012. Selective suppression of harmful cyanobacteria in an entire lake with hydrogen peroxide. Water Research 46: 1460-1472.

Matthijs, H. C. P., D. Jančula, P. M. Visser \& B. Maršálek, 2016. Existing and emerging cyanocidal compounds: new perspectives for cyanobacterial bloom mitigation. Aquatic Ecology 50: 443-460.

Meijer, M.-L. 2000. Biomanipulation on The Netherlands. 15 years of experience. PhD-thesis Wageningen University, ISBN 90-5808-226-1.

Moss, B., 2010. Ecology of freshwaters. A view for the twentyfirst century, 4th ed. Wiley, Chichester.

Moss, B., S. Kosten, M. Meerhoff, R. W. Battarbee, E. Jeppesen, N. Mazzeo, K. Havens, G. Lacerot, Z. Liu, L. De Meester, H. Paerl \& M. Scheffer, 2011. Allied attack: climate change and eutrophication. Inland Waters 1: 101-105.

Mucci, M., N. Pessoa Noyma, L. de Magalhães, M. Miranda, F. van Oosterhout, I. Alves Guedes, V. L. M. Huszar, M. Manzi Marinho \& M. Lürling, 2017. Chitosan as coagulant on cyanobacteria in lake restoration management may cause rapid cell lysis. Water Research 118: 121-130.

Newcombe, G., J. House, L. Ho, P. Baker \& M. Burch, 2010. Management strategies for cyanobacteria (blue-green algae): a guide for water utilities. WQRA, Research Report 74, ISBN 1876616245.

Nimptsch, J., S. Woelf, S. Osorio, J. Valenzuela, C. Moreira, V. Ramos, R. Castelo-Branco, P. Nuno Leão \& V. Vasconcelos, 2016. First record of toxins associated with cyanobacterial blooms in oligotrophic North Patagonian lakes of Chile - a genomic approach. International Review of Hydrobiology 101: 57-68.

Noordhuis, R., B. G. van Zuidam, E. T. H. M. Peeters \& G. J. van Geest, 2016. Further improvements in water quality of the Dutch Borderlakes: two types of clear states at different nutrient levels. Aquatic Ecology 50: 521-539.

Noyma, N., L. de Magalhães, L. Lima Furtado, M. Mucci, F. van Oosterhout, V. L. M. Huszar, M. M. Marinho \& M. Lürling, 2016. Controlling cyanobacterial blooms through effective flocculation and sedimentation with combined use of flocculants and phosphorus adsorbing natural soil and modified clay. Water Research 97: 26-38.

Noyma, N. P., L. de Magalhães, M. Miranda, M. Mucci, F. van Oosterhout, V. L. M. Huszar, M. M. Marinho, E. R. A. Lima \& M. Lürling, 2017. Coagulant plus ballast technique provides a rapid mitigation of cyanobacterial nuisance. PLoS ONE 12(6): e0178976.

Nürnberg, G. K., 2007. Lake responses to long-term hypolimnetic withdrawal treatments. Lake and Reservoir Management 23(4): 388-409.

Nürnberg, G. K., 2019. Hypolimnetic withdrawal as a lake restoration technique: determination of feasibility and continued benefits. Hydrobiologia. https://doi.org/10.1007/ s10750-019-04094-z.

OECD, 2014. Water governance in the Netherlands: fit for the future? OECD Studies on Water. https://doi.org/10.1787/ 9789264102637-en.

O’Neil, J. M., T. W. Davis, M. A. Burford \& C. J. Gobler, 2012. The rise of harmful cyanobacteria blooms: the potential roles of eutrophication and climate change. Harmful Algae 14: 313-334.

Osgood, R. A., 2017. Inadequacy of best management practices for restoring eutrophic lakes in the United States: guidance for policy and practice. Inland Waters 7(4): 401-407.

Paerl, H. W. \& J. Huisman, 2008. Blooms like it hot. Science 320(5872): 57-58.

Paerl, H. W. \& V. Paul, 2012. Climate change: links to global expansion of harmful cyanobacteria. Water Research 46: 1349-1363.

Pan, G., H. Zou, H. Chen \& X. Yuan, 2006. Removal of harmful cyanobacterial blooms in Taihu Lake using local soils III. Factors affecting the removal efficiency and an in situ field experiment using chitosan modified local soils. Environment Pollution 141(2): 206-212.

Pan, G., B. Yang, D. Wang, H. Chen, B. H. Tian, M. L. Zhang, X. Z. Yuan \& J. Chen, 2011. In-lake algal bloom removal and submerged vegetation restoration using modified local soils. Ecology Engineering 37(2): 302-308.

Parma, S., 1980. The history of the eutrophication concept and the eutrophication in the Netherlands. Hydrobiological Bulletin 14: 5-11.

Peterson, H. G., C. Boutin, K. E. Freemark \& P. A. Martin, 1997. Toxicity of hexazinone and diquat to green algae, diatoms, cyanobacteria and duckweed. Aquatic Toxicology 39: 111-134.

PHN, 2017. Province Noord-Holland, Uitvoeringsprogramma Oostelijke Vechtplassen, Report PNH-20171206/935022 (in Dutch).

Pilgrim, K. M. \& P. L. Brezonik, 2005. Treatment of lake inflows with alum for phosphorus removal. Lake and Reservoir Management 21(1): 1-9.

Poléo, A. B. S., 1995. Aluminium polymerization: a mechanism of acute toxicity of aqueous aluminium to fish. Aquatic Toxicology 31: 347-356.

Quaak, M., J. van der Does, P. Boers \& J. van der Vlugt, 1993. A new technique to reduce internal phosphorus loading by inlake phosphate fixation in shallow lakes. Hydrobiologia 253(1-3): 337-344.

Rabalais, N. N., 2002. Nitrogen in aquatic ecosystems. Ambio 31(2): 102-112.

Reynolds, C. S., G. H. M. Jaworski, H. A. Cmiech \& G. F. Leedale, 1981. On the annual cycle of the blue-green alga Microcystis aeruginosa kütz. Philosophical Transactions of the Royal Society B 293(1068): 419-477. 
Rissman, A. R. \& S. R. Carpenter, 2015. Progress on nonpoint pollution: barriers \& opportunities. Daedalus 144(3): 35-47.

Roozen, F. C. J. M., M. Lürling, H. Vlek, E. A. J. Van Der Pouw Kraan, B. W. Ibelings \& M. Scheffer, 2007. Resuspension of algal cells by benthivorous fish boosts phytoplankton biomass and alters community structure in shallow lakes. Freshwater Biology 52: 977-987.

Ryding, S.-O. \& C. Forsberg, 1976. Six polluted lakes: a preliminary evaluation of the treatment and recovery processes. Ambio 5(4): 151-156.

Scheffer, M., S. H. Hosper, M.-L. Meijer, B. Moss \& E. Jeppesen, 1993. Alternative equilibria in shallow lakes. Trends in Ecology and Evolution 8: 275-279.

Scheffer, M., A. Gragnani, L. R. Mur \& E. H. van Nes, 1997. On the dominance of filamentous cyanobacteria in shallow, turbid lakes. Ecology 78: 272-282.

Scheffer, M. \& E. H. van Nes, 2007. Shallow lakes theory revisited: various alternative regimes driven by climate, nutrients, depth and lake size. Hydrobiologia 584: 455-466.

Scott, J. T., M. J. McCarthy \& H. W. Paerl, 2019. Nitrogen transformations differentially affect nutrient-limited primary production in lakes of varying trophic state. Limnology \& Oceanography Letters 4(4): 96-104.

Sharpley, A., H. P. Jarvie, A. Buda, L. May, B. M. Spears \& P. Kleinman, 2013. Phosphorus legacy: overcoming the effects of past management practices to mitigate future water quality impairment. Journal of Environmental Quality 42: 1308-1326.

Sinha, E., A. M. Michalak \& V. Balaji, 2017. Eutrophication will increase during the 21 st century as a result of precipitation changes. Science 357: 405-408.

Smith, V. H., G. D. Tilman \& J. C. Nekola, 1999. Eutrophication: impacts of excess nutrient inputs on freshwater, marine, and terrestrial ecosystems. Environment Pollution 100: 179-196.

Smith, V. H. \& D. W. Schindler, 2009. Eutrophication science: where do we go from here? Trends Ecology Evolution 24: 201-207.

Smolders, A. J. P., L. P. M. Lamers, E. C. H. E. T. Lucassen, G. Van Der Velde \& J. G. M. Roelofs, 2006. Internal eutrophication: how it works and what to do about it-a review. Chemistry and Ecology 22(2): 93-111.

Søndergaard, M., E. Jeppesen, T. L. Lauridsen, C. Skov, E. H. van Nes, R. Roijackers, E. Lammens \& R. Portielje, 2007. Lake restoration: successes, failures and long-term effects. Journal of Applied Ecology 44: 1095-1105.

Spears, B., E. Mackay, S. Yasseri, I. Gunn, K. Waters, C. Andrews, S. Cole, M. De Ville, A. Kelly, S. S. Mei, A. Moore, G. Nürnberg, F. van Oosterhout, J. Pitt, G. Madgwick, H. Woods \& M. Lürling, 2016. A meta-analysis of water quality and aquatic macrophyte responses in 18 lakes treated with lanthanum modified bentonite (Phoslock ${ }^{\circledR}$ ). Water Research 97: 111-121.

Stroom, J. M. \& W. E. A. Kardinaal, 2016. How to combat cyanobacterial blooms: strategy toward preventive lake restoration and reactive control measures. Aquatic Ecology 50(3): 541-557.

Torres, G. S., L. H. S. Silva, L. M. Rangel, J. L. Attayde \& V. L. M. Huszar, 2016. Cyanobacteria are controlled by omnivorous filter-feeding fish (Nile tilapia) in a tropical eutrophic reservoir. Hydrobiologia 765: 115-129.

Triest, L., I. Stiers \& S. Van Onsem, 2016. Biomanipulation as a nature-based solution to reduce cyanobacterial blooms. Aquatic Ecology 50: 461-483.

Urrutia-Cordero, P., M. K. Ekvall \& L.-A. Hansson, 2016. Controlling harmful cyanobacteria: taxa-specific responses of cyanobacteria to grazing by large-bodied daphnia in a biomanipulation scenario. PLoS ONE 11(4): e0153032.

Van de Graaf, J. 2016. BlueBusters. aanpak blauwalgenoverlast met bijvangst 2015-2016. Presentation at Platform Ecological Restoration of Lakes Meeting, May 12th 2016. [available at: https://www.helpdeskwater.nl/onderwerpen/ water-ruimte/ecologie/platform-meren/lezingen/ @ 177492/lezingen-pehm-12-mei/].

Van der Veer, B., R. F. van Nieuwenhuyze \& M. Donze, 1993. Accumulation of blue-green algal scums in small harbours and its prevention. Verhandlungen des Internationalen Verein Limnologie 25: 610-613.

Van Donk, E., M. P. Grimm, P. G. M. Heuts, G. Blom, K. Everards \& O. F. R. van Tongeren, 1994. Use of mesocosms in a shallow eutrophic lake to study the effects of different restoration measures. Archiv fur Hydrobiologie 40: 283-294.

Van Liere, L. \& R. D. Gulati, 1992. Restoration and recovery of shallow eutrophic lake ecosystems in The Netherlands: epilogue. Hydrobiologia 233: 283-287.

van Loosdrecht, M. C. M. \& D. Brdjanovic, 2014. Anticipating the next century of wastewater treatment. Science 344(6191): 1452-1453.

Van Nes, E. H., M. Scheffer, M. S. van den Berg \& H. Coops, 2002. Aquatic macrophytes: restore, eradicate or is there a compromise? Aquatic Botany 72: 387-403.

van Oosterhout, F., S. Yasseri, N. Noyma, V. Huszar, M. M. Marinho, M. Mucci, G. Waajen, \& M. Lürling, Evaluation of a whole lake eutrophication management technique using combined flocculation and in situ phosphorus immobilization. Inland Waters, submitted.

Verpoorter, C., T. Kutser, D. A. Seekell \& L. J. Tranvik, 2014. A global inventory of lakes based on high-resolution satellite imagery. Geophysical Research Letters 41: 6396-6402.

Visser, P. M., B. W. Ibelings, M. Bormans \& J. Huisman, 2016. Artificial mixing to control cyanobacterial blooms: a review. Aquatic Ecology 50: 423-441.

Waajen, G. W. A. M., E. J. Faassen \& M. Lürling, 2014. Eutrophic urban ponds suffer from cyanobacterial blooms: Dutch examples. Environment Science Pollution Research 21: 9983-9994.

Waajen, G., F. van Oosterhout \& G. Douglas, 2016a. Management of eutrophication in Lake De Kuil (The Netherlands) using combined flocculant: lanthanum modified bentonite treatment. Water Research 97: 83-95.

Waajen, G. W. A. M., N. C. B. Van Bruggen, L. M. D. Pires, W. Lengkeek \& M. Lürling, 2016b. Biomanipulation with quagga mussels (Dreissena rostriformis bugensis) to control harmful algal blooms in eutrophic urban ponds. Ecological Engineering 90: 141-150.

Watson, S. B., E. McCauley \& J. A. Downing, 1997. Patterns in phytoplankton taxonomic composition across temperate lakes of differing nutrient source. Limnology Oceanography 42: 487-495. 
WWAP (United Nations World Water Assessment Programme), 2017. The United Nations World Water Development Report 2017. Wastewater: the Untapped Resource. UNESCO, Paris.

Zhong, J.-C., J.-H. Yu, X.-L. Zheng, S.-L. Wen, D.-H. Liu \& C.X. Fan, 2018. Effects of dredging season on sediment properties and nutrient fluxes across the sediment-water interface in Meiliang bay of Lake Taihu, China. Water 10: 1606.

Publisher's Note Springer Nature remains neutral with regard to jurisdictional claims in published maps and institutional affiliations. 